\title{
Autoimmune Disease in Women: Endocrine Transition and Risk Across the Lifespan
}

\author{
Maunil K. Desai ${ }^{1}$ and Roberta Diaz Brinton ${ }^{2,3 *}$ \\ ${ }^{1}$ School of Pharmacy, University of Southern California, Los Angeles, CA, United States, ${ }^{2}$ Center for Innovation in Brain \\ Science, University of Arizona, Tucson, AZ, United States, ${ }^{3}$ Departments of Pharmacology and Neurology, College of \\ Medicine, University of Arizona, Tucson, AZ, United States
}

OPEN ACCESS

Edited by:

Vincent Geenen,

University of Liège, Belgium

Reviewed by:

Sonia Berrih-Aknin

Institut National de la Santé et de la Recherche Médicale (INSERM),

France

Corrado Betterle

University of Padova, Italy

*Correspondence:

Roberta Diaz Brinton rbrinton@email.arizona.edu

Specialty section:

This article was submitted to Neuroendocrine Science,

a section of the journal

Frontiers in Endocrinology

Received: 29 November 2018

Accepted: 10 April 2019

Published: 29 April 2019

Citation:

Desai MK and Brinton RD (2019)

Autoimmune Disease in Women: Endocrine Transition and Risk Across

the Lifespan.

Front. Endocrinol. 10:265

doi: 10.3389/fendo.2019.00265
Women have a higher incidence and prevalence of autoimmune diseases than men, and $85 \%$ or more patients of multiple autoimmune diseases are female. Women undergo sweeping endocrinological changes at least twice during their lifetime, puberty and menopause, with many women undergoing an additional transition: pregnancy, which may or may not be accompanied by breastfeeding. These endocrinological transitions exert significant effects on the immune system due to interactions between the hormonal milieu, innate, and adaptive immune systems as well as pro- and anti-inflammatory cytokines, and thereby modulate the susceptibility of women to autoimmune diseases. Conversely, pre-existing autoimmune diseases themselves impact endocrine transitions. Concentration-dependent effects of estrogen on the immune system; the role of progesterone, androgens, leptin, oxytocin, and prolactin; and the interplay between Th1 and Th2 immune responses together maintain a delicate balance between host defense, immunological tolerance and autoimmunity. In this review, multiple autoimmune diseases have been analyzed in the context of each of the three endocrinological transitions in women. We provide evidence from human epidemiological data and animal studies that endocrine transitions exert profound impact on the development of autoimmune diseases in women through complex mechanisms. Greater understanding of endocrine transitions and their role in autoimmune diseases could aid in prediction, prevention, and cures of these debilitating diseases in women.

Keywords: women, autoimmne disease, menopause, puberty, gender differences

\section{KEY POINTS}

- Women undergo three major endocrinological transitions: puberty, pregnancy and menopause.

- These endocrine transitions exert a significant influence on the innate and adaptive immune system due to the interaction between the hormonal milieu, innate and adaptive immune system as well as pro- and anti-inflammatory cytokines.

- Concentration-dependent effects of estrogen on the immune system, the role of progesterone, androgens, leptin, oxytocin and prolactin; and the interplay between Th1 and Th2 immune responses together maintain a delicate balance between defense against pathogens, immunological tolerance, and autoimmunity.

- Human epidemiological data, animal studies, and mechanistic experiments have demonstrated a strong link between endocrine transition states in women and development of certain autoimmune diseases such as multiple sclerosis, systemic lupus erythematosus, type 1 diabetes mellitus, rheumatoid arthritis, and psoriasis. 
- Greater understanding of endocrine transitions and their role in autoimmune diseases could aid in prediction, prevention, and cures of these debilitating diseases in women.

\section{ENDOCRINE TRANSITIONS IN WOMEN INCREASE THEIR SUSCEPTIBILITY TO AUTOIMMUNE DISEASES}

\section{Introduction}

Autoimmune (AI) diseases include over 80 disorders and are the third most common category of disease in the United States after cancer and cardiovascular disease, affecting $\sim 5$ to $8 \%$ of the population or 14.7 to 23.5 million people $(1,2)$. While the clinical manifestations of AI diseases vary in terms of affected tissues, age of onset, and response to immunosuppressive treatments, a shared feature of all AI diseases is the contribution of host immune-mediated responses to tissue injury (3). AI diseases are the result of a complex interaction between genetic and environmental factors, and most of these factors have not yet been definitively identified (4).

Women constitute $\sim 78 \%$ of those affected by autoimmune diseases, bearing a disproportionate burden of the high morbidity associated with these chronic conditions (5-8). Female sex is a risk factor for polyautoimmunity (9). The "gender gap" in autoimmunity has been well known for over 20 years $(10,11)$ and AI diseases are a leading cause of death among young and middle-aged women (12). Figure 1 enumerates the gender differences in prevalence of autoimmune diseases $(8,13-20)$.

AI diseases have a strong gender-specific component with female hormones playing a major immunomodulatory role that depends on their concentration in the bloodstream, the concomitant levels of other hormones, and the age of the host (21). Commencing at puberty, women undergo cyclical hormonal changes until menopause, called menstrual cycle which makes pregnancy possible $(22,23)$. Pregnancy and postgestational phases are characterized by hormonal fluctuations that have a long-lasting holistic impact on women's health (24). Menopause is a state of reproductive senescence when menses cease and is preceded by a 3-4 year period of irregular reproductive function known as the perimenopausal transition stage (25). In a rat model, which mimics both endocrine and chronological aging observed in women (26), perimenopause was characterized by a decline in expression of genes involved in bioenergetics, as well as differential regulation of the inflammatory response (26). There is evidence that the changing hormonal milieu during the menopausal transition, and its effect on inflammatory processes plays a role in the increased susceptibility of peri- and post-menopausal women to autoimmune diseases (Table 1) (27-29). For example, in women aged around 50 years, neutrophil percentage dropped whilst lymphocyte percentage rose (30), subjecting perimenopausal women to increased risk of lymphocyte mediated autoimmune diseases.

The dynamic hormonal milieu during these transitions is significant from the perspective of sexual and reproductive health, but also influences other aspects of female health, such as susceptibility to infection and autoimmunity, tissue integrity, ophthalmology, movement, cognition, disability, and overall quality of life. A better understanding of these transitions and their association with autoimmune diseases represents a critical component of women's health.

\section{Autoimmune Diseases and Endocrine Transition States}

Below five relatively common autoimmune diseases, namely Multiple Sclerosis, Systemic Lupus Erythematosus, Type 1 Diabetes Mellitus, Rheumatoid Arthritis, and Psoriasis, have been discussed in the context of endocrinological transition states in women: puberty, pregnancy, and menopause.

\section{Multiple Sclerosis}

Multiple sclerosis (MS) is largely prevalent among women of reproductive age and is less common in men, with twice as many women affected as men (31). However, disease progression and neurodegeneration occur more rapidly in men (32). MS is closely linked to the female reproductive and hormonal cycle, and the majority of cases of MS in adolescence are observed post-puberty (33).

Over the past six decades the absolute number of cases of MS has increased with the increase in the female-to-male sex ratio among patients. The sex ratio among MS patients was reported to be 1.4 in 1955 (34), reaching a 2:1 ratio in the 1980s (35), approaching a ratio of $3: 1$ in mid-2000s $(36,37)$ and then surpassing it in recent years (38-41). MS after 50 years of age is greater in women and exhibit a more rapidly degenerating phenotype. Postmenopausal status has been associated with increased disease severity, even adjusting for disease duration and type, and earlier age at menopause also appeared to have a strong correlation with increased disease severity (42).

\section{Puberty}

Pediatric MS, defined as MS diagnosis at $<8$ years of age has been observed in $\sim 3-5 \%$ of MS patients (43-45), while MS onset after the age of 50 years (known as Late-Onset MS or LOMS) occurs in $\sim 5 \%$ of patients (46). Pre-pubertal MS onset is uncommon $(47,48)$, however, the incidence of MS increases after puberty (45, 47-49). The sex ratio of MS incidence is approximately equal in children $<13$ years of age (pre-pubertal) but increases to $2.2: 1$ with double the number of females affected in the 1318 years age group $(45,47,48)$. Acute demyelinating disorders (ADS) such as transverse myelitis (50) and acute disseminated encephalomyelitis (51) are more common among children $<10$ years of age and show no female preponderance. However, in women, chronic demyelinating diseases, such as MS and neuromyelitis optica, are more frequent post-puberty than in men $(33,45,47,48,50,51)$. Ahn et al. (52), reported that female children with ADS and a later age of menarche were less likely to be diagnosed with MS. MS patients showed a spike in relapse risk only during the peri-menarche transition, and a peak in disease onset was observed 2 years after menarche (53). Earlier age at menarche has been shown to increase the risk of MS in female subjects significantly ( $p$-value $=0.00017$ ), while in male subjects the association between the risk of MS and earlier age at puberty 


\section{Autoimmune diseases impact women more than men}

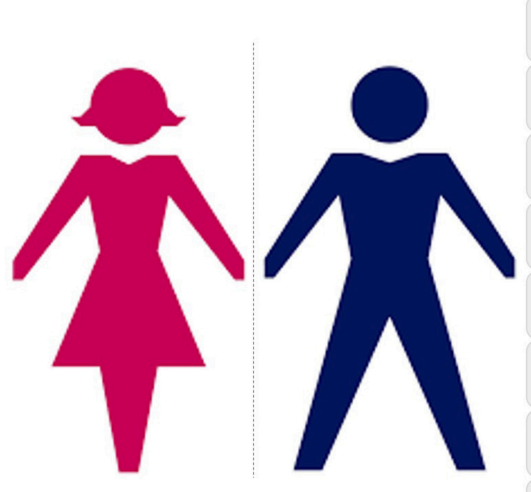

Systemic lupus erythematosus

6:1 (12)

Rheumatoid arthritis (adult)

3:1 (13)

Rheumatoid arthritis (juvenile)

2:1 (14)

Multiple sclerosis

2:1 (15)

Type 1 diabetes mellitus

1:1 (16) 1:2

(17)

Sjögren disease

9:1 (13)

Psoriasis

$1: 1.44(21)$

Autoimmune hepatitis

4:1 (18) 6:1

(19)

FIGURE 1 | Sex differences in prevalence ratio of autoimmune diseases. Autoimmune diseases are significantly more prevalent in women than men.

TABLE 1 | Autoimmune diseases and transition states.

\begin{tabular}{|c|c|c|c|}
\hline & Puberty & Pregnancy & Menopause \\
\hline T1DM & $\begin{array}{l}\text { - Peak incidence between } 5 \text { and } 7 \text { years and at puberty. } \\
\text { - Greater risk of complications in girls. }\end{array}$ & $\begin{array}{l}\text { - Worsens pregnancy outcome vs. T2DM. } \\
\text { - Thyroid antibodies associated with } \\
\text { Gestational DM but lack predictive value. } \\
\text { - High TSH and thyroid autoimmunity increase } \\
\text { GDM risk. }\end{array}$ & $\begin{array}{l}\text { - Females with T1Dm have higher mortality than } \\
\text { - Men. } \\
\text { microvascular complications in T1DM result in pre- } \\
\text { - Women bear unequal burden of sequelae of } \\
\text { T1DM vs. men. }\end{array}$ \\
\hline RA & - Earlier age at menarche increases risk. & - Pregnancy and breast feeding is protective. & $\begin{array}{l}\text { - Irregular menstrual cycle increases risk. } \\
\text { - Early age at menopause significantly associated } \\
\text { with RA. } \\
\text { - More joint destruction in post-menopausal } \\
\text { women. } \\
\text { - HRT protective. }\end{array}$ \\
\hline MS & $\begin{array}{l}\text { - Sex ratio rises to } 2.2: 1 \text { post-puberty. } \\
\text { - Late menarche decreases risk (females-only). } \\
\text { - Pre-pubertal ovariectomy decreases risk. } \\
\text { - Spike in relapse during peri-menarche and incidence } \\
\text { peak post-menarche. } \\
\text { - Higher leptin in females may increase risk. }\end{array}$ & $\begin{array}{l}\text { - Relapse rate reduced during pregnancy but } \\
\text { worsens after delivery. } \\
\text { - Breast-feeding reduces relapse. }\end{array}$ & $\begin{array}{l}\text { - Peak incidence in perimenopausal age group. } \\
\text { - Post-menopausal women have worse symptoms } \\
\text { and higher severity. } \\
\text { - More frequently primary progressive MS than } \\
\text { relapsing-remitting MS in post-menopausal } \\
\text { age group. }\end{array}$ \\
\hline Psoriasis & - Perimenarchal increase in incidence. & $\begin{array}{l}\text { - Decreased severity during pregnancy. } \\
\text { - Higher estrogen and higher E2 to } \\
\text { progesterone ratio results in improvement. }\end{array}$ & $\begin{array}{l}\text { - Post-menopausal exacerbation of psoriasis. } \\
\text { - Late onset psoriasis is more common in women } \\
\text { than in men. }\end{array}$ \\
\hline
\end{tabular}

was not found to be significant (54). Clinical and epidemiological observations have led to the conclusion that puberty increases the risk of MS, with post-pubertal females more likely to develop MS than post-pubertal males of the same age group.

\section{Pregnancy}

A systematic review (55) of 22 publications confirms the reduction of relapses during pregnancy, due to increased levels of sex hormones produced (56). MS symptoms also vary during the menstrual cycle (57). Pregnancy has a protective effect on MS. For pregnant MS patients, the relapse frequency of MS was reduced to half during the latter half of pregnancy (18 weeks gestation and beyond), and during the third trimester the relapse rate was found to be lower by $70 \%$ than in the pre-pregnancy state (58-63). After delivery, MS worsened, with frequent relapses in the postpartum period with the highest relapse frequency 
observed to occur within 3 months of delivery (64). In a Danish study (65), childbirth was found to reduce the risk of MS by $\sim 46 \%$ for 5 years following the pregnancy and pregnancies terminated early also conferred protective effect on the risk of developing MS, suggesting that temporary immunosuppression during pregnancy served to protect pregnant women from MS in the period immediately following the pregnancy.

\section{Menopause}

A British study published in 2014 (66) reported a peak incidence of MS in women between the ages of 40 and 55 years (perimenopausal and menopausal age group). The authors concluded that divergent trends in MS incidence in women and men were established around puberty (12-16 years) and the increased MS incidence in women did not converge with the incidence in men until $\sim 60$ years of age (post-menopausal).

Disease progression was comparable among men and women with Late Onset MS (LOMS), defined as MS diagnosis in persons over 50 years of age, while in patients with MS onset at a younger age ( $<40$ years), disease progression was more rapid among men than among women, although the disease is more common in women (46). Bove et al. also noted a greater proportion of men in the LOMS cohort (female: male ratio of 1.86) than in the Adult Onset MS (AOMS) cohort (female: male ratio 2.84) cohort (46). This association suggests that female sex may be a risk factor for an earlier presentation of MS, during the reproductive years, or alternatively, that male sex may have a protective effect. Additionally, misdiagnosis of MS in older patients might be a common phenomenon (67) and delays in diagnosis up to 4.7 years have been reported $(68,69)$, due to unusual presentation of the disease (70).

Common symptoms shared between menopause and MS include fatigue, urologic, affective, cognitive, and vasomotor symptoms (71). Declining estrogen levels during the perimenopausal transition have been associated with immunological alterations comparable to those observed in MS, which include increased secretion of pro-inflammatory cytokines (IL1, IL6, TNF-alpha) and decreased production of anti-inflammatory cytokines (72). Accelerated cognitive decline has been associated with menopause; this is suggested to result from loss of ovarian estrogens leading to impaired brain repair mechanisms and eventual neurodegeneration $(26,71,73,74)$. Therefore, menopause may alter the immune, inflammatory, and neurodegenerative aspects of reproductive aging, independent of the effects of the MS disease process itself and contribute to the misdiagnosis or delayed diagnosis of MS in peri- and post-menopausal women, as described earlier.

In persons with LOMS, it has been observed that the MS disease type at onset was less frequently relapsing remitting ( $80 \%$ for LOMS vs. $95 \%$ for AOMS in female patients); the primary progressive course was more frequently rapidly evolving, with fewer relapses or new gadolinium enhancing lesions; and symptoms more frequently involved motor and coordination symptoms and less frequently involved visual symptoms, compared to individuals with AOMS disease (70, 75-78).

\section{Systemic Lupus Erythematosus (SLE)}

Systemic lupus erythematosus (SLE) affects a significantly greater number of women than men $(13,79-81)$. The Michigan Lupus Epidemiology and Surveillance Program (81) reported an increased incidence and prevalence of SLE in women across all ethnicities. The female to male ratio of SLE incidence was 6:1 and SLE prevalence was 10:1, and incidence rates were higher in African American female subjects compared to Caucasian female subjects (81). In late childhood, a trend of increased incidence of SLE was observed among African American girls compared to Caucasian girls (81). In the 20-50 year range, an early incidence peak of SLE has been reported in African American women but there were no significant differences in SLE incidence between African American and Caucasian women after the average age of menopause (81), calculated to be 51 years in the US (82). Globally, estrogen levels were shown to be higher in Asian (Japanese) and African (Bantu) women than in Caucasian women (83) which explains the observation that SLE is more prevalent in some ethnic groups, such as Afro-Americans and Asians, since SLE is antibody-mediated and higher estrogen levels favor antibody-mediated Th2 immune response (84).

A Japanese study (85) stratified patients with SLE by age and sex distribution and found that the overall female to male ratio of SLE was 8.2:1. Furthermore, while the prevalence of SLE among women showed two peaks, between ages 35-39 years and ages 55-59 years, no significant age-dependent peaks were observed among men (85). An epidemiological study in an $80 \%$ Caucasian population in Minnesota reported that SLE prevalence peaked between the age 40-49 years (perimenopausal) among women and then decreased sharply in the 50-59 years age group while incidence of SLE in women peaks between the ages of 20 and 29 years, and between the ages of 50 and 59 years (79). The incidence of SLE in men remained low until the 60-69 years age group, increasing thereafter, with a peak in men $>70$ years of age (79). Men $>60$ years of age have a higher prevalence of SLE compared to younger men (79). A study published in the UK (13) supports the hypothesis that transitional states in women may play a major role in the development of autoimmune diseases such as SLE. This retrospective cohort study, conducted using the CPRD, a longitudinal database of UK general practice records incepted in 1987 and believed to be representative of the UK population, found that the peak SLE incidence rate was observed in 40-49 years age group among women (perimenopausal) and in the 60-69 years age group among men (13), similar to the Minnesota study (79). The incidence rate of SLE in women fell sharply in the 60-69 years group (postmenopausal), suggesting that risk of autoimmune diseases like SLE may decline in the postmenopausal age group $(13,79)$.

\section{Puberty}

The female-to-male ratio in SLE has been reported to vary between 2:1 and 6:1 before puberty, 7:1 to $15: 1$ after puberty, and $3: 1$ to $8: 1$ post-menopause $(86,87)$, suggesting that, in women, the increase in hormone levels during puberty enhances the risk of development of autoimmune states. An epidemiological study from Taiwan (88) noted a substantial increase in the prevalence of juvenile SLE among Taiwanese girls compared to 
boys of the same age. Prevalence of SLE in girls was 0.65 per 100,000 children at age one, increasing to 6.7 per 100,000 at age seven, and increasing further to 34.6 per 100,000 at age 15 (88). The prevalence figure for boys was almost zero per 100,000 at ages one and seven, increasing to 7.8 per 100,000 at age 15 (88). The 7-15 years age group spans the pre-pubertal and pubertal years for females in Taiwan with the average age of menarche being 12.1 years (89). The multifold jump in juvenile lupus prevalence in female subjects is an indication that endocrinological transition, i.e., puberty, may play an influential role in immunomodulatory function and correlate with increased susceptibility to autoimmune diseases during the peripubertal transition. Titers and prevalence of antinuclear antibody (ANA), a marker for lupus, increased in children through puberty, particularly among girls (90).

Patients suffering from Cutaneous Lupus Erythematosus (CLE), a variant of SLE, demonstrate equal sex distribution with a female to male ratio of 1:1, but the female to male ratio of CLE patients rose to 4.5:1 if the disease onset was at or after the age of 12 (91). Different sex ratios have been reported according to the subtypes of CLE. Acute CLE has the highest female to male ratio (12:1) while chronic CLE had an almost equal ratio of 1.1:1 (91). Above observations suggest a role of puberty in the development of SLE.

Conversely, SLE exerts sexually dimorphic effects young male and female patients. A study exploring the effect of lupus on height found that there was a significant $(p$-value $<0.0001$ ) reduction in the parent-adjusted height $\mathrm{z}$ score with time in girls compared to boys (92). The mean menarche age was higher among juvenile patients with SLE than in controls ( $p$-value $=0.0008$ ) despite comparable maternal menarche age in both groups (93).

\section{Pregnancy}

E2 concentrations are abnormally low in pregnant patients with SLE during periods of increased disease activity, compared with pregnant women not suffering from SLE $(94,95)$. Serum prolactin and disease activity of SLE have been positively associated in multiple studies (96-100). Abnormally high prolactin levels during pregnancy in SLE also positively correlate with disease activity $(95,101)$. Furthermore, two double-blind, placebo-controlled human studies have shown that suppression of prolactin with bromocriptine, which also increases estradiol concentration (102) reduces SLE disease activity (103-105). Exacerbation of SLE is more common during the pre-menstrual period and pregnancy, during which women experience increased estrogen levels (84). This phenomenon is in contrast with other autoimmune diseases such as MS, psoriasis and T1DM, which are mediated by T lymphocytes, while SLE is a disease mediated by autoantibodies producing-B lymphocytes; and $\mathrm{E} 2$, throughout its concentration range, has been shown to stimulate antibody production by B cells (106).

\section{Menopause}

The female to male incidence ratio of 2.6 is significantly lower in the late onset SLE group ( $>50$ years age) than in the early onset SLE group in which the ratio is 13.2 (107). Furthermore, there is evidence that early age at menarche, oral contraceptive use, early age at menopause, surgical menopause, and postmenopausal use of hormones were associated with an increased risk of SLE (108). Women suffering from SLE and undergoing menopausal transition show a decreased frequency of exacerbations of SLE after menopause, a decreased SLE Disease Activity Index (SLEDAI), but a greater accumulation of damage in the affected organs from each discrete exacerbation in the postmenopausal period (109-112).

\section{Type I Diabetes Mellitus (T1DM) Puberty}

Unlike other AI diseases such as MS, RA and SLE, the incidence and prevalence of type 1 diabetes is slightly higher in men and boys than in women and girls (113). The epidemiological data in the International Diabetes Federation Atlas 2013 (6th edition) indicate there are $\sim 500,000$ known cases of children ( $0-14$ years) with T1DM worldwide and $50-60 \%$ of cases are diagnosed before the age of 15 years (114). A study in the Swedish population (18) found that there were no differences between the sexes in the incidence rate of T1DM in children aged between 3 months and 14 years. For both sexes the incidence of type 1 diabetes peaked twice, first between 5 and 7 years of age, and then at or near puberty (115). The incidence of T1DM in subjects aged between 15 and 39 years is twice that in men compared to women (115). There are fewer cases of T1DM in subjects aged 40 years or above, and in this age group the incidence of T1DM is comparable between men and women (115). In contrast to the Swedish study, a Japanese study assessing 77 male and 95 female participants found that although the incidence of T1DM in the prepubertal age group was comparable between the sexes, while it was higher among female subjects in the pubertal age group (116).

While the above observations indicate that globally male children and adults form the majority of T1DM patients, it is important to note that girls and women suffer from morbid sequelae of T1DM more often than males. The development of T1DM during the pubertal transition in girls is associated with a range of conditions. Girls suffering from T1DM are at a greater risk of excessive weight gain and adiposity during puberty, which may exacerbate insulin resistance (117). Adolescent girls with T1DM are more prone to hyperandrogenism or polycystic ovary syndrome phenotype, potentially adding to the cardiovascular risk profile of these patients (117). End Stage Renal Disease (ESRD) is a serious complication of T1DM (118). Among female patients, pubertal onset (onset between 10 and 19 years of age) of T1DM confers the highest risk of development of ESRD compared to prepubertal onset of T1DM (onset $<10$ years of age) or adult onset of T1DM (onset $>20$ years of age) (119). Furthermore, female subjects are at a $29 \%$ higher risk of developing retinopathy as a complication of T1DM compared to male subjects (120). Young adult women (20-29 years) with T1DM lose the cardiovascular protection that is otherwise seen in the general female population, and exhibit similar rates of ischemic heart disease as those observed in adult men of 18-49 years of age with T1DM (121-123). Increased insulin resistance has been observed among girls at all Tanner stages of pubertal development (124) compared to boys at the same 
stages, even adjusting for adiposity, Body Mass Index, waist, or hip circumference. In peri-pubertal girls with T1DM, lower sex hormone binding globulin (SHBG) and high free androgen index (FAI) are associated with higher Body Mass Index Standard Deviation Scores (BMI-SDS) and higher total daily insulin per kilogram bodyweight $(125,126)$.

Therefore, as the evidence above demonstrates, even though there are more boys with T1DM than girls, girls remain more susceptible to the sequelae of T1DM and these sequelae are exacerbated by pubertal onset of T1DM.

\section{Pregnancy}

Pregnant women with diabetes mellitus are affected by either T1DM, T2DM or gestational diabetes (GDM). Pregnancy outcomes differ depending on the type of diabetes. Pregnant women with T2DM had lower Hemoglobin A1c (marker of longterm control of blood glucose) and lower insulin requirements, lower maternal weight gain, fewer cesarean deliveries, and gestational age at birth was significantly higher than women with T1DM (127). While fetal losses occurred in both T1DM and T2DM groups, intermediate and late term fetal losses were significantly less common among T1DM patients, and T1DM patients had significantly more fetal losses due to congenital anomalies or prematurity compared to T2DM patients (128). Furthermore, T1DM patients have a higher incidence of complications and of poor pregnancy outcomes than those with T2DM (129). These observations show that while poorly controlled hyperglycemia is a primary characteristic of both T1DM and T2DM, pregnancy outcomes are worse among women with pre-existing T1DM.

\section{Gestational diabetes}

Gestational diabetes is defined as an intolerance to glucose that is first diagnosed or has its onset during pregnancy (130). Close associations have been documented between GDM and immune system. An increase in number and proportion of different subsets of $\mathrm{T}$ lymphocytes have been documented in pregnant women suffering from GDM (131-136). Alterations in proportion of regulatory $\mathrm{T}$ cell $\left(\mathrm{T}_{\text {reg }}\right)$ subpopulations (137) have also been observed in these women along with reduced function of immunosuppressive $\mathrm{T}_{\text {reg }}$ cells (137).

A recent meta-analysis (138) concluded that there was a significant association between thyroid antibodies and the risk of GDM but thyroid antibodies measured in the first trimester in pregnant women lacked predictive value for the risk of GDM. Furthermore, presence of thyroid antibodies may not increase the risk of GDM in pregnant women who have a normally functioning thyroid gland (138), although higher than normal thyroid-stimulating hormone (TSH) levels $(\geq 2.5 \mathrm{mU} / \mathrm{mL})$ in pregnant women are associated with GDM (139).

Adiposity-induced inflammation in pregnancy (140), and antigenic load of the fetus (141) have both been implicated as causes in the development of GDM but sex steroid may have a role to play as well $(142,143)$. It was found that first-trimester Sex Hormone Binding Globulin (SHBG) values were inversely associated with an increased risk of the development of GDM that was diagnosed at 26 to 30 weeks of gestation (144); the association was independent of the influence of maternal weight and other important variables that included age, race, and smoking.

Women with autoimmune GDM are more likely than women with non-autoimmune GDM to show pancreatic autoantibody positivity (145). Even though both pregnancy with GDM (146) and healthy pregnancy (147) may be associated with an increased production of thyroid antibodies and altered thyroid function, a combination of high TSH and thyroid autoimmunity in early pregnancy resulted in a 4 -fold increase in the risk of GDM, as well as increasing the risk of adverse pregnancy outcomes (148). Anti-thyroid peroxidase (anti-TPO) has been detected in $\sim 10$ $16 \%$ of all pregnant women tested $(146,148)$ and in $80 \%$ of women who were screened specifically for GDM; however only $26 \%$ of all women who exhibited anti-TPO in their blood had a GDM diagnosis according to WHO criteria (149), suggesting that measurement of anti-TPO antibodies has low specificity for GDM screening.

Based on these observations it is likely that hormone fluctuations during pregnancy may play a role in the development of GDM and subsequent progression to T1DM.

\section{Menopause}

No significant differences were observed in age at menopause in women with T1DM, compared to controls in a 2011 Finnish study (150). These results contradicted previous studies reporting an earlier menopause age among women with T1DM, that claimed an average decrease in reproductive years by $17 \%$ (151). However, the Finnish study did note that patients with microvascular complications due to diabetes had a significantly earlier menopause (150). A meta-analysis (123), which included data from 200,000 participants, found a significant and clinically meaningful difference in the excess risk of mortality in female patients with T1DM compared to male patients, particularly in relation to mortality due to vascular causes. For macrovascular outcomes, such as cardiovascular and renal disease, the excess risk of mortality in women compared with men was even more prominent which could be due to the greater effect of hyperglycemia and diabetes seen in women than in men $(152,153)$.

In conclusion, young girls and women are more likely to be in a persistent state of poor glycemic control than young boys and men $(154,155)$, starting at puberty (124, $156,157)$. An additional contributing factor is the disturbance in the hypothalamic-pituitary-ovarian axis in women, which triggers a chain of endocrinological events, starting with delayed menarche, menstrual irregularities and early menopause (158). As a result, even though the incidence and prevalence of T1DM in women may be equal to or lower than those reported among men, women bear an unequal burden of the disease and its sequelae throughout their lifetime, which is attributable to the endocrinological milieu unique to women.

\section{Rheumatoid Arthritis (RA)}

A study published in 1990 involving 564 patients with RA (159) reported an overall female to male incidence ratio of 2.3; however, with increasing age the female to male ratio decreased from 3.7 before 30 years of age to 1 after the 6th decade of life. The 
study also suggested that the average woman develops the first symptoms of RA at the time of menopause (159), with a peak age of RA onset around menopause (160). However, recent studies have suggested that overall prevalence of RA is four times higher in women than in men, and female to male incidence ratio of RA increases with age and is three to five times higher in reproductive and perimenopausal age group $(161,162)$ and in three regions in the world, namely, America, Europe and Western Pacific, over four out of five RA patients are women (162). Synovial fluid level of estrogens relative to androgens were found to be significantly elevated in both male and female patients with RA $(163,164)$.

\section{Puberty}

The polymorphism rs2476601 has been found to be significantly associated with juvenile RA in female but not in male patients, with evidence of a genotype-by-sex interaction (165). Early menarche at age $<12$ years was inversely associated with RA $(166,167)$ and found to be protective factor in one study $(168)$. A study on an Egyptian population of boys and girls with juvenile rheumatoid arthritis found no significant difference in pubertal delay between male and female patients with RA in that country (169).

\section{Pregnancy}

Pregnancy and breastfeeding have been found to be a protective factor for RA (160, 170-172). The Swedish Nurses' Health Study, which was a 26-yearlong follow-up study with more than 120,000 female participants revealed that breastfeeding for $>12$ months was inversely associated with the development of $\mathrm{RA}$, and demonstrated decreased risk of RA in postmenopausal women with a history of long-term breast feeding (173). The effect was dose-dependent and remained significant after adjustment for smoking and level of education (173). Irregular menstrual cycles and earlier age at menarche increased the risk of RA while other reproductive hormonal factors were not associated with an increased RA risk (173). A study on Chinese women in Guangzhou, China arrived at a similar conclusion that breastfeeding, especially of longer duration, but not oral contraceptive use, was positively associated with a lower risk of RA (174).

Possible explanations for the protective effect of breast feeding include long-term immunomodulation, such as the development of progesterone receptors on lymphocytes, dysregulated hypothalamic-pituitary-adrenal axis, and differences in cortisol concentrations. Lankarani-Fard et al. (175) measured cortisol concentrations in postmenopausal women, and noted significantly higher concentrations in those who had breast fed. In contrast, short-term breast-feeding may actually increase RA risk (176). Oxytocin, one of the hormones that is raised in women who breast feed, is known to reduce cortisol concentrations (177), induce well-being, and lower blood pressure in the mothers (178). Prolactin, which also is increased during breast feeding, is a known immunostimulator (179), and high concentrations of prolactin are seen in patients with RA $(180,181)$.

These observations suggest differential short-term and long-term effects of breast feeding on the immune system, and consequently on susceptibility to RA based on variable concentrations of different sex hormones before, during and after pregnancy.

\section{Menopause}

Early age at menopause ( $\leq 40-45$ years) was found to be statistically significantly associated (182) with the subsequent development of rheumatoid factor (RF)-negative RA, whereas it was positively correlated with RF-positive RA, but the association did not reach statistical significance. The effect of early menopause on development of RA remained significant after adjusting for smoking, level of education, and length of breastfeeding $(166,183)$. The Canadian Early Arthritis Cohort Study on the other hand found that early age at menopause is significantly associated with seropositivity in women with early RA (184). An observational cohort study of RA patients enrolled in the Swiss Clinical Quality Management Program for Rheumatoid Arthritis, published in 2018, discovered that in women with RA, functional disability progression was less favorable in post-menopausal women compared to premenopausal women and was not explained by disease duration, age or radiographic damage (185) and a similar study in US women found that menopause is associated with a worsening progression of functional decline (186). A cohort study focusing on pathological joint damage found that although patients $>60$ years of age of both sexes suffering from RA had greater joint damage compared to younger patients (both male and female), older postmenopausal female patients had most severe disease in terms of joint destruction and physical disability (187). The study concluded that the menopausal state is responsible for the major part of the differences in outcome between men and women in RA (187). This conclusion is also supported by a populationbased control study (188) demonstrating the protective effect of post-menopausal hormone therapy in RA.

\section{Psoriasis}

Prominent increase in incidence of psoriasis is observed in the sixth decade of life which corresponds to the postmenopausal period (189-191). Another set of studies found a bimodal distribution of ages of onset for psoriasis; puberty and between the ages of 30 and 50 years (192-194).

\section{Puberty}

The peripubertal increase in the prevalence of psoriasis may be explained by the increase in sex hormones during this period since sex hormones are known to promote keratinocyte differentiation (195). High levels of estrogens seem to have a regulatory and inhibiting effect on many components of the immune response, while low levels can be stimulating (106, 196, 197) and similar to other $\mathrm{T}$ cell mediated autoimmune diseases, such as MS and RA, estrogen is protective in psoriasis.

\section{Pregnancy}

Psoriatic body surface area (BSA) was found to significantly decrease between the 10th and the 20th week of gestation compared to that in controls, while BSA significantly increased by 6 weeks postpartum (198) suggesting protective role of pregnancy in psoriasis. Pregnancy's natural immunomodulation 
is associated with alleviation of symptoms in patients suffering from psoriasis $(199,200)$. A number of studies have investigated the association between hormones and psoriasis (201-203). A worsening of psoriatic symptoms has been observed postpartum, prior to menses, and at menopause, concomitant with decrease in estrogen and progesterone levels, while most patients undergoing hormone therapy around menopause noted no change in their symptoms. Although progesterone levels alone did not correlate with changes in psoriatic symptoms among pregnant women, a higher ratio of estrogen to progesterone resulted in improvement in symptoms in a group of 47 patients (198).

\section{Menopause}

A decrease in estrogen level during menopause was reported to affect the occurrence or exacerbation of psoriasis in patients already suffering from the condition, and it has been postulated that reduced estrogen levels lead to insufficient inhibition of Th1 cell-mediated responses in menopausal women and consequent disease exacerbation (204).

\section{Mechanistic Perspective: Hormones, Transition States, and Epigenetics}

MS, RA, Psoriasis and T1DM are considered to be Th1 mediated autoimmune diseases while in case of SLE, Th2-mediated autoimmunity is believed to predominate. However, at least one study found a Th2-skewed immune response in adult patients with T1DM (205).

\section{Endocrine Transition and Autoimmunity: Reproductive Hormones}

T-cell-mediated autoimmunity is upregulated post-puberty, as demonstrated by Ahn et al. (52) who observed that female post-pubertal mice developed enhanced myelin-reactive T-cell responses, compared to age-matched mice that had been prevented from entering puberty via pre-pubertal ovariectomy. Similarly, Makino et al. (206) demonstrated a reduced incidence of type 1 diabetes mellitus (T1DM) with pre-pubertal ovariectomy in non-obese female diabetic mice, whereas pre-pubertal castration in male mice increased the risk of T1DM suggesting inherent protection enjoyed by the male sex. A study also demonstrated hormone-dependent gender-specific splenic immune response post-puberty where female mice exhibited higher expression of adaptive immune response genes while male mice had higher innate immune response genes' expression (207). A significant gender-dependent divergence in serum immunoglobulins levels was also noted in the study (207). No statistically significant pre-pubertal differences were noted in this study.

Estrogen Receptor-alpha is expressed in pancreatic beta cells and sex hormones also exert effects on beta cell function (208). Exogenous estrogen might limit islet amyloid polypeptidemediated beta cell loss in mice (209). Even though increased prevalence and severity of islet amyloid deposition has been identified in males compared to females with Type 2 Diabetes Mellitus (T2DM) (210), in T1DM, beta cell destruction was increased in females compared to males after puberty (211), potentially due to the influence of sex hormones on the immune system in the immune-mediated T1DM. Puberty may accelerate onset of T1DM in genetically susceptible females, mediated by the effect of estrogen on the Interleukin-6 (IL6) promoter (212). Anti-islet autoantibodies have been detected years before clinical diagnosis of T1DM (213) and these antibodies, which play an important role in T1DM disease development, are more frequently inherited paternally than maternally, even though frequencies of these autoantibodies were found equal in male and female offspring (214).

During peripubertal thymic involution, androgens stimulate $\mathrm{CD} 8+$ cells and reduce the CD4+/CD8 + ratio, which diminishes cell-mediated immune responses in male mice and rats, while estrogen has the opposite effect, supporting CD4+ T cell survival $(215,216)$. Compared to healthy women serum testosterone was reduced in women suffering from Th1-mediated autoimmune disease such as MS, particularly during the active phase of the disease, as documented by brain MRI, while no significant difference was seen in sex hormone levels between men suffering from MS and healthy men (217). Estrogen may be both pro- (218) and anti-inflammatory (219), depending on the circulating levels in the blood as well as cell-specific receptor activation $(49,220)$. High-estrogen states seem to favor amelioration of symptoms in T-cell mediated autoimmune disorders such as MS and RA, while a low-estrogen state is associated with disease progression (221).

Important role of estrogens in SLE pathogenesis has been long-suspected but the molecular mechanisms involved remain to be definitively elucidated $(222,223)$; however recent evidence suggests that rapid turnover of ER-alpha receptor molecules in $\mathrm{T}$ cells from SLE patients due to cellular level alterations in the ubiquitination signaling pathway may be responsible (224).

Estrogen was also found to inhibit the production of IL-12 and TNF-alpha (203), suppress antigen-presenting capacity in dendritic cells, and normalize type 1-shifted $\mathrm{T}$ cell priming by dendritic cells (225) as well as stimulate anti-inflammatory IL-10 production in dendritic cells and T cells (226), thereby conferring protective effect on women in the reproductive age group against Th1-mediated psoriasis.

Both early (four weeks of age) and late (12 weeks of age) estrogen administration protected non-obese diabetic (NOD) mice from spontaneous autoimmune diabetes up to 30 weeks of age via revival of invariant natural killer $\mathrm{T}$ (iNKT) cells' immunomodulatory function (227). Early estrogen administration averts insulitis that would signal loss on pancreatic beta cells and delayed treatment ameliorates insulitis to thwart the destruction of inflamed islets through what the authors described as "bystander effect" (227).

Hormonal fluctuations in pregnancy (228) and the associated exacerbations of SLE are well-documented (229, 230). Estrogen has been traditionally associated with $\operatorname{SLE}(231,232)$. At plasma levels experienced during pregnancy, estrogen inhibits Th1mediated pathways, through mediators such as interleukin-1 (IL-1), interleukin 6 (IL-6), tumor necrosis factor-alpha (TNF$\alpha$ ), suppresses the activity of natural killer (NK) cells, and stimulates Th2-mediated pathways, through mediators such as interleunkin-4 (IL-4), interleukin-10 (IL-10), and Transforming Growth Factor-beta (TGF $\beta$ ) (106), as well as enhances the number and function of $\mathrm{CD} 4+\mathrm{CD} 25+$ regulatory $\mathrm{T}$ cells 
(233, 234). At lower concentrations than those observed during pregnancy, estrogen stimulates release of Th2-response mediating cytokines, promotes NK cell activity (106) and stimulates antibody production by B cells (106). In fact, a 1year pilot study (235) in 16 patients demonstrated that blocking estrogen receptors in vivo by an estrogen selective receptor downregulator could be considered as a new and relatively safe therapeutic approach in the management of SLE patients with moderately active disease.

During the perimenopausal transition, declining levels of estrogen and dehydroepiandrosterone sulfate may be associated with increased production of Th1 cytokines such as IL-1, IL6 , TNF- $\alpha$, and increased response to these cytokines, decreased secretion of Th2 cytokines, decreased lymphocyte levels (CD4+ T cells, B cells), and decreased cytotoxic activity of NK cells (236).

Based on above observations, it is clear that hormones significantly affect the immune system (86) and there is strong evidence that estrogens have immunomodulatory effects (237-239). The role of hormone replacement therapy and estrogen receptor modulators in autoimmune diseases is being explored (240-246).

Thyroid autoimmunity has been described as a "window" into autoimmune states and has been covered in multiple reviews (247-249). Individuals suffering from more than one autoimmune disease are likely to have a co-existing thyroid autoimmune state as well, which may have been present in either clinical or subclinical form since first diagnosis of another autoimmune disease (248). It is possible that hormonal flux in susceptible women may trigger or precipitate downstream changes that disturb the fragile balance between inflammation and immune regulation, similar to a neurological "tipping point" described in perimenopause that results in hypometabolism, insomnia, depression and ultimately neurological decline (250).

\section{Endocrine Transition and Autoimmunity: Other Factors}

Leptin has been implicated as another hormone potentially responsible for the sexual dimorphism in post-puberty autoimmune diseases (251). Leptin is necessary for the induction of MS in in leptin-deficient, C57BL/6J-ob/ob mice (252). Leptin levels continue to rise in post-pubertal females, but not in males due to the suppressive effect of testosterone on leptin secretion (253). Furthermore, injection of recombinant leptin in male mice increases their susceptibility to developing experimental autoimmune encephalomyelitis (254). Obesity and therefore leptin are implicated as central triggers of unnecessary or aggressive inflammatory state responsible for autoimmune states and the increased incidence of autoimmunity could be a function of increased leptin, while in men testosterone acts as an immunosuppressant. This hypothesis is lent credence by a study in patients with Hashimoto's thyroiditis (both hypothyroid and euthyroid) where body mass index and fat mass was higher in patients compared to controls (255).

Prolactin is another pro-inflammatory hormone implicated in development of autoimmune diseases due to its increased concentrations found in post-pubertal females compared to men (179). Significantly higher prevalence of autoimmune thyroid diseases was found in female prolactinoma patients compared to age-matched healthy women (256). Similarly, SLE patients had higher leptin levels compared to controls and these levels were correlated with disease activity and severity (257). Increased leptin in SLE also showed an inverse correlation with the frequency of $\mathrm{T}_{\text {reg }}$ cells (257).

Not all autoimmune pathogenesis can be attributed to hormonal influence. Etiopathogenesis of Th2-mediated autoimmune diseases such as SLE has been attributed to the sexual dimorphism of the immune response, initiated in the gut mucosa (258). Female mice were found to have higher plasma cell- and gut-imprinted- $\alpha 4 \beta 7 \mathrm{~T}$ cell frequencies, markedly higher CD45+ immune cell densities, and higher numbers of IL-17-, IL-22-, and IL-9-producing cells in the lamina propria compared to male counterparts (258).

Prepubertal pediatric autoimmune diseases such as Juvenile Rheumatic Arthritis peak between the ages of two and four when levels of both estrogen and testosterone are low (259) and direct hormonal influence on autoimmunity is likely minimal. In utero sex steroid levels are much higher than in childhood but reach low levels after birth, but approximately around the 6-month mark estrogen and testosterone levels reach between one-fifth to one-third of adult levels in female and male children, respectively, and this period has been termed "mini-puberty" (260). It is possible that this rise in levels of sex hormones soon after birth primes genetically susceptible individuals to develop autoimmune diseases in early childhood or later in life. Epigenetic mechanisms, discussed later, could also play a role in prepubertal autoimmune diseases (261-265).

Pregnancy results in a shift from a pro-inflammatory and cell-mediated (Th1) type of immune response to an antiinflammatory and antibody-mediated (Th2) type of immune response, which promotes fetal survival due to diminished Th1 responses involved in rejection of the fetus as an allograft (266). After pregnancy, Th1 immune-mediated diseases reappear (267-270). Pregnancy has little effect on long-term disability in women suffering from MS according to some sources $(32,271)$, although one study found pregnancy and childbirth associated with less long-term disability (272). Breastfeeding is protective in Th1 mediated disease and women with MS who breastfed were found to have an almost 50\% lower risk of post-partum relapse (273) compared to women who did not breastfeed. Although breastfeeding seemed to protect women from relapse, a considerable body of literature covered in an excellent review (274) implicates prolactin as one of the causes of the postpartum surge in MS symptoms, and this phenomenon is similar to higher prolactin levels found in post-pubertal female subjects that plays a role in increasing their susceptibility to Th1-mediated autoimmune diseases (179). This contrasting phenomenon can be explained by the observation that prolonged breastfeeding was found to decrease proinflammatory CD4+ tumor necrosis factor$\alpha$-producing cells in both healthy women and women with MS, but cell counts increased again after menses resumed (275).

With respect to gestational diabetes, changes in concentrations of two chemokines-an increase in level of the chemokine Monocyte Chemotactic Peptide (MCP)-1 levels, and decrease in levels of another chemokine, RANTES (Regulated on Activation Normal T-cell Expressed and Secreted)-is implicated in the pathogenesis (276). MCP-1 
is a pro-inflammatory activator of several immune cells (277), and RANTES is an immunomodulator suppressing the maternal allogeneic response (278). In diabetic pregnancies, increase in MCP-1 and decrease in RANTES will elevate proinflammatory response and attenuate the immunosuppressive effect of RANTES.

\section{Endocrine Transition and Autoimmunity: Influence of Epigenetics}

Recently it has come to light that the autoimmune regulator (AIRE) is key to central tolerance of self-antigens and hormonal action affects the expression of AIRE mRNA and protein (279). Estrogen as well as male castration downregulated

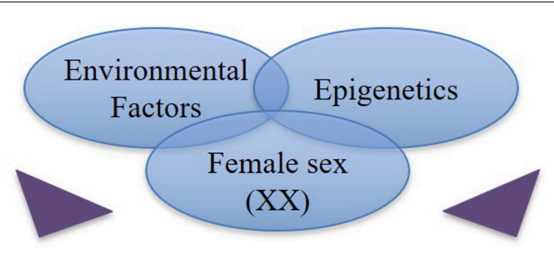

\section{Modifying Factors Endocrine Transitions}

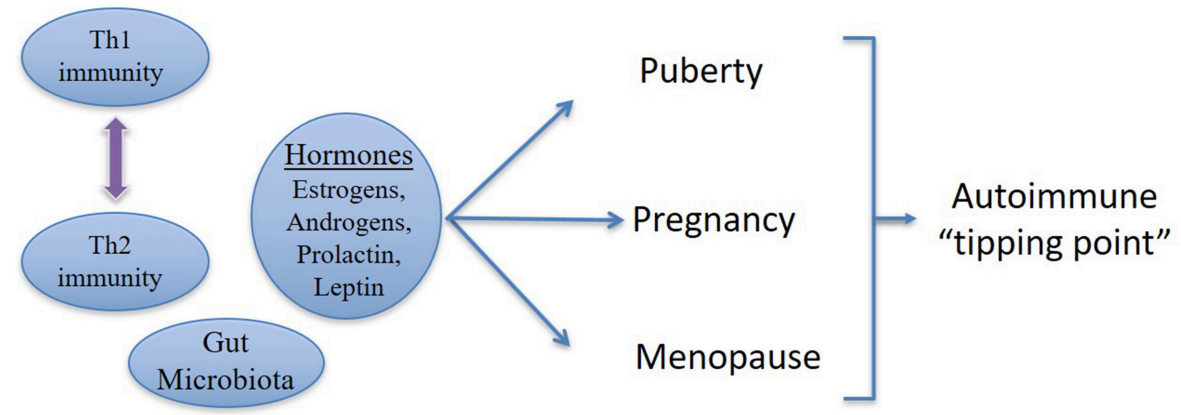

FIGURE 2 | Factors that contribute to increased incidence and prevalence of autoimmunity in women. In women (46XX) with genetic susceptibility to autoimmune states, external environmental stimuli affect modifying factors as well as endocrine transitions via epigenetic mechanisms. Additionally, there are interactions between estrogens, androgens, leptin and prolactin on one hand and the interplay between Th1 and Th2 immune responses on the other. Both (endocrine and immune response) these phenomena are influenced in varying ways during the female transition states depending on the circulating concentrations of different hormones and immune cytokines, which in turn may be determined by epigenetics. Thus, hormonal fluctuation, immune polarization and transition states together drive susceptible women over the autoimmune "tipping point" leading to manifestation of overt clinical disease.

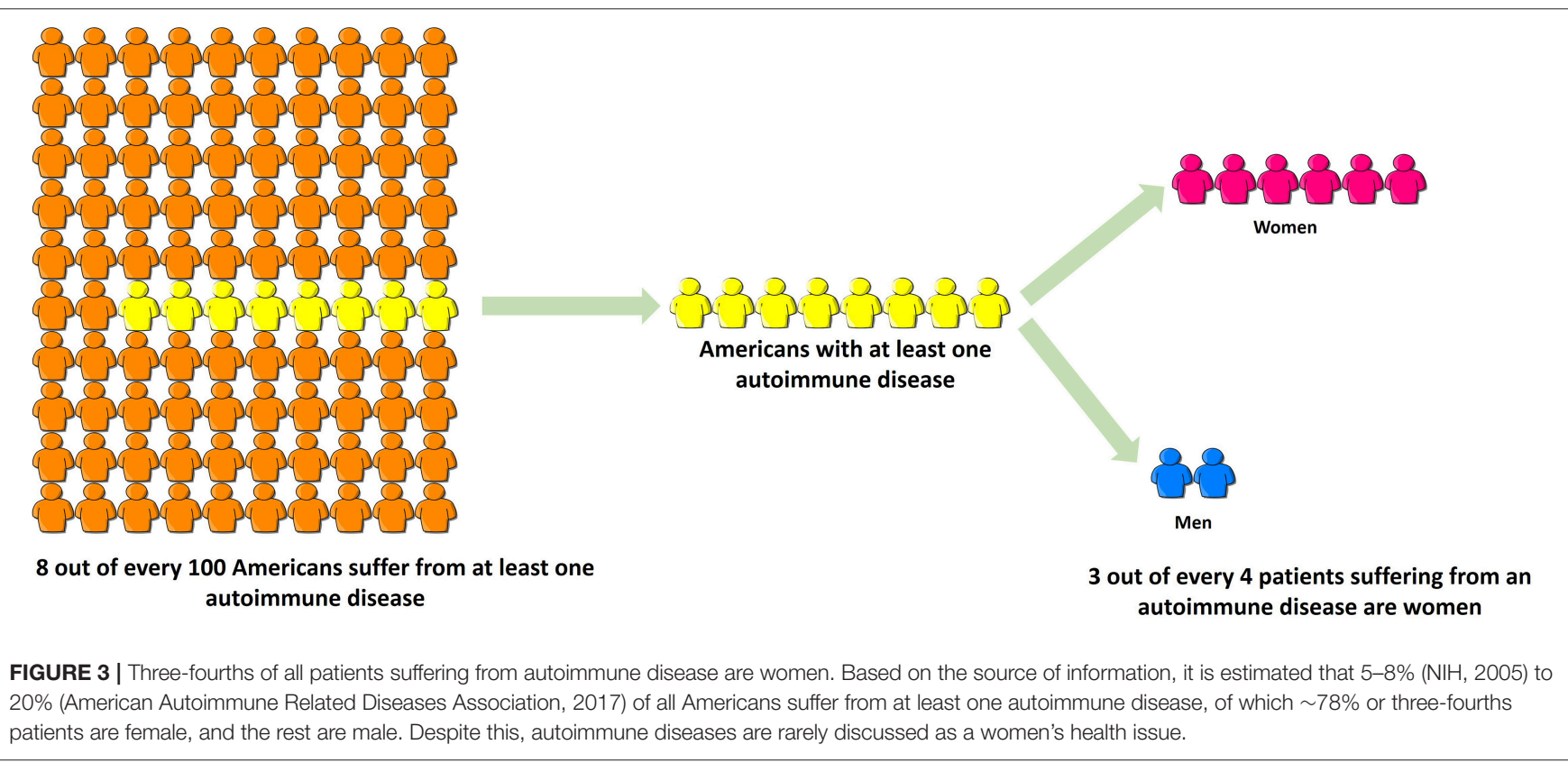


AIRE, while estrogen-mediated methylation of $\mathrm{CpG}$ sites in the promotor region of AIRE could potentially disturb the delicate balance between autoreactive $\mathrm{T}$ cells and $\mathrm{T}_{\text {reg }}$ cells, precipitating clinical autoimmune disease(s) in the presence of environmental trigger(s) (279). The role of epigenetics and DNA methylation was also explored by our lab and we found that DNA methylation plays a key role in progression toward reproductive senescence (280), which could have crucial implications for autoimmune states observed in post-menopausal women. Inhibition of DNA methylation expedited transition to reproductive senescence in female Sprague-Dawley rats, while increased methylation through methionine supplementation prolonged the period of endocrine aging by preserving regular cycling (280). Another theory suggests that environmental toxins termed "endocrine disruptors" play a key role in the increased incidence of autoimmune diseases, cancer and diabetes by altering the genome and the epigenome (281). Age related immune dysfunction in innate and adaptive immune system regulated via epigenetic mechanisms has been observed (282) and implicated in autoimmune disease states. Epigenetically induced immunosenescence potentially leads to elevated levels of proinflammatory cytokines during the aging process either due to accumulated toxins or the normal aging process or both and consequently increases the susceptibility to autoimmune diseases in aging (283). These age-related changes occur in both sexes but testosterone's immunosuppressant function and its decline much later in life (284) compared to estrogen's varying effects on the immune system, hormonal flux in women and earlier loss due to menopause amplify the effects of immune system-related changes in females compared to males. Epigenetic mechanisms of MS (285), SLE (286, 287), RA (288), T1DM (289) and psoriasis (290) has been studied in some detail but further elucidation is necessary to fully understand the role of epigenetics as a driver of menopausal transition and autoimmunity in females.

Similar to menopause, puberty too has a strong epigenetic component as articulated by Toro et al. (291), and epigenetic mechanisms are likely a bridge between external non-genetic stimuli (environment, nutrition, physical activity) and genomic expression or repression that serves to modulate puberty. In fact, Thompson et al. (292) discovered that in females, puberty associated DNA methylation changes at CpGs are in close proximity to estrogen responsive genes and form networks centered on respiratory and inflammatory processes. Moreover, the authors suggest that these epigenetic changes that materialize during puberty in females likely contribute to the sexual dimorphism of immune-mediated diseases later in life (292). Some of these epigenetic mechanisms could be DNA methylation, histone post-translational modifications and noncoding RNAs (291) that have been known to influence various autoimmune diseases $(293,294)$. To add to this complexity, Markle et al. (295) showed that microbial exposure in early-life affects level of sex hormones and influences autoimmune states in non-obese diabetic mice via sex hormone regulation. Male NOD mice were conferred protection against T1DM by gut microbiota and this protection was transferable to immature female NOD mice via transfer of microbiota, which increased testosterone in the female mice, reduced islet cell inflammation and decreased antibody production (295).
Based on these observations, the epigenetic regulation of perimenopausal and peripubertal transition states could be the missing link that connects hormonal flux, genetic susceptibility and environmental stimuli in the initiation, pathogenesis and clinical manifestation of autoimmune diseases. Future studies can shed light on the exact molecular pathways as well as clarify causal relationships between the different factors that ultimately cause autoimmune disease states to manifest.

\section{CONCLUSION}

Autoimmune disease states show strong associations with endocrinological changes in human and animal studies. There is clear evidence for the role of sex steroids in the immune disturbances that result in autoimmune diseases (Figure 2). The majority of women who pass through the different endocrinological transition states do not succumb to autoimmune diseases.

However, a small percentage of women emerge with an increased risk of developing autoimmune diseases due to sustained hormonal changes during the endocrinological transitions coupled with genetic susceptibility and environmental injury, which are likely modulated by epigenetic mechanisms. In women there are interactions between estrogens, androgens, leptin and prolactin on one hand and the interplay between Th1 and Th2 immune responses on the other. Both (endocrine hormones and immune responses) these phenomena are influenced in varying ways during the female transition states depending on the concentration of different hormones and immune cytokines. Thus, hormonal fluctuation, immune polarization, and transition states together increase the susceptibility of women to autoimmune diseases.

Autoimmune diseases are highly debilitating diseases with no cure and only moderately satisfactory but expensive treatment that nonetheless increases patients' vulnerability to deadly infections due to prolonged immunosuppression. Autoimmune diseases result in considerable erosion in quality of life, unemployment or underemployment and increased caregiver hours. Based on the source of information, it is estimated that $5-8 \%$ (1) to $20 \%$ (American Autoimmune Related Diseases Association; https://www.aarda.org/knowledgebase/many-americans-autoimmune-disease/; accessed on Nov. 20, 2018) of all Americans suffer from at least one autoimmune disease, of which $\sim 78 \%$ or three-fourths patients are female, and the rest are male (Figure 3) (296). Despite this, autoimmune diseases are rarely discussed as a women's health issue. The incidence and prevalence rates of various autoimmune diseases are rising all over the world $(297,298)$. At the global level, increased incidence and prevalence of autoimmune diseases in Western and Northern countries compared to Southern and Eastern countries has led to speculation that alterations in dietary habits such as highly prevalent Western diet, increased exposure to pollution as well as a changing environment may be responsible for this region-specific rise (297). The National Institutes of Allergy and Infectious Diseases (NIAID) in 2011 estimated that the cost of treating autoimmune disease in the US is $>\$ 100$ billion annually (299); this excludes indirect costs 
to the patient and family members incurred due to decreased quality of life and loss of productivity. In contrast, autoimmune diseases research funding from $\mathrm{NIH}$ was $\$ 883$ million in FY 2016 and \$821 million in FY 2015 (300). Recently women's health issues have received more attention, and considering autoimmune diseases are a leading cause of death among young and middle-aged women in the United States (12), the plight of autoimmune disease patients should not go unnoticed. Increased funding for research in autoimmune diseases and exploring their link to endocrine transitions, raising awareness among healthcare providers and the general population and developing better support systems for both men and women suffering from autoimmune diseases are some ways to mitigate the toll autoimmune diseases take on our society.

Greater understanding of: (1) the underlying cellular and molecular level immune changes due to endocrinological transitions; (2) the genetic and epigenetic characteristics

\section{REFERENCES}

1. Autoimmune Diseases Coordinating Committee. Progress in Autoimmune Diseases Research: Report to Congress. US Department of Health and Human Services (2005).

2. Rose NR, Mackay IR. Prospectus: the road to autoimmune disease. In: Rose NR, Mackay IR, editors. The Autoimmune Diseases. 4th ed. St. Louis, MO: Academic Press (2006). p. xix-xxv.

3. Yuksel N. Women's health across the lifespan: a pharmacotherapeutic approach. Can J Hosp Pharm. (2011) 64:153. doi: 10.4212/cjhp.v64i2.1001

4. Lleo A, Invernizzi P, Gao B, Podda M, Gershwin ME. Definition of human autoimmunity - autoantibodies versus autoimmune disease. Autoimmun Rev. (2010) 9:A259-66. doi: 10.1016/j.autrev.2009.12.002

5. Dooley MA, Hogan SL. Environmental epidemiology and risk factors for autoimmune disease. Curr Opin Rheumatol. (2003) 15:99-103. doi: 10.1097/00002281-200303000-00002

6. Gleicher N, Barad DH. Gender as risk factor for autoimmune diseases. J Autoimmun. (2007) 28:1-6. doi: 10.1016/j.jaut.2006.12.004

7. Jacobson DL, Gange SJ, Rose NR, Graham NM. Epidemiology and estimated population burden of selected autoimmune diseases in the United States. Clin Immunol Immunopathol. (1997) 84:223-43. doi: 10.1006/clin.1997.4412

8. Cooper GS, Stroehla BC. The epidemiology of autoimmune diseases. Autoimmun Rev. (2003) 2:119-25. doi: 10.1016/S1568-9972(03)00006-5

9. Rojas-Villarraga A, Toro CE, Espinosa G, Rodríguez-Velosa Y, DuarteRey C, Mantilla RD, et al. Factors influencing polyautoimmunity in systemic lupus erythematosus. Autoimmun Rev. (2010) 9:229-32. doi: 10.1016/j.autrev.2009.10.001

10. McCarthy M. The "gender gap" in autoimmune disease. Lancet. (2000) 356:1088. doi: 10.1016/S0140-6736(05)74535-9

11. Petri M. Gender-based differences in autoimmunity and autoimmune disease. J Women's Health. (1995) 4:433-6. doi: 10.1089/jwh.1995.4.433

12. Walsh SJ, Rau LM. Autoimmune diseases: a leading cause of death among young and middle-aged women in the United States. Am J Public Health. (2000) 90:1463-6. doi: 10.2105/AJPH.90.9.1463

13. Rees F, Doherty M, Grainge M, Davenport G, Lanyon P, Zhang W. The incidence and prevalence of systemic lupus erythematosus in the UK, 1999-2012. Ann Rheum Dis. (2016) 75:136-41. doi: 10.1136/annrheumdis-2014-206334

14. van Vollenhoven RF. Sex differences in rheumatoid arthritis: more than meets the eye. BMC Med. (2009) 7:12. doi: 10.1186/1741-7015-7-12

15. Thierry S, Fautrel B, Lemelle I, Guillemin F. Prevalence and incidence of juvenile idiopathic arthritis: a systematic review. Joint Bone Spine. (2014) 81:112-7. doi: 10.1016/j.jbspin.2013. 09.003 of women who have increased likelihood of developing autoimmune diseases; and the (3) translational animal models currently used to study endocrinological transition states in women could help predict, potentially prevent and even cure the debilitating group of autoimmune diseases in women.

\section{AUTHOR CONTRIBUTIONS}

All authors listed have made a substantial, direct and intellectual contribution to the work, and approved it for publication.

\section{FUNDING}

This work was supported by National Institute on Aging (NIA) grants P01AG026572 and R37AG053589 to RB.

16. Magyari M. Gender differences in multiple sclerosis epidemiology and treatment response. Mult Scler. (2014) 20:124451. doi: $10.1177 / 1352458514521515$

17. Maahs DM, West NA, Lawrence JM, Mayer-Davis EJ. Epidemiology of type 1 diabetes. Endocrinol Metab Clin North Am. (2010) 39:48197. doi: 10.1016/j.ecl.2010.05.011

18. Wandell PE, Carlsson AC. Time trends and gender differences in incidence and prevalence of type 1 diabetes in Sweden. Curr Diabetes Rev. (2013) 9:342-9. doi: 10.2174/15733998113099990064

19. Guy J, Peters MG. Liver disease in women: the influence of gender on epidemiology, natural history, and patient outcomes. Gastroenterol Hepatol. (2013) 9:633-9.

20. Kim BH, Choi HY, Ki M, Kim KA, Jang ES, Jeong SH. Population-based prevalence, incidence, and disease burden of autoimmune hepatitis in South Korea. PLoS ONE. (2017) 12:e0182391. doi: 10.1371/journal.pone.0182391

21. Nussinovitch U, Shoenfeld Y. The role of gender and organ specific autoimmunity. Autoimmun Rev. (2012) 11:A37785. doi: 10.1016/j.autrev.2011.11.001

22. Silverthorn DU, Ober WC, Garrison CW, Silverthorn AC, Johnson BR. Human Physiology: An Integrated Approach. San Francisco, CA: Pearson/Benjamin Cummings (2004).

23. Sherwood L. Human Physiology: From Cells to Systems. Cengage Learning (2015).

24. Gardner DG, Shoback DM. Greenspan's Basic \& Clinical Endocrinology. New York, NY: McGraw-Hill Medical (2007).

25. Rannevik G, Jeppsson S, Johnell O, Bjerre B, Laurell-Borulf Y, Svanberg L. A longitudinal study of the perimenopausal transition: altered profiles of steroid and pituitary hormones, SHBG and bone mineral density. Maturitas. (1995) 21:103-13. doi: 10.1016/0378-5122(94)00869-9

26. Yin F, Yao J, Sancheti H, Feng T, Melcangi RC, Morgan TE, et al. The perimenopausal aging transition in the female rat brain: decline in bioenergetic systems and synaptic plasticity. Neurobiol Aging. (2015) 36:2282-95. doi: 10.1016/j.neurobiolaging.2015.03.013

27. Molnár I, Bohaty I, Somogyiné-Vári É. High prevalence of increased interleukin-17A serum levels in postmenopausal estrogen deficiency. Menopause. (2014) 21:749-52. doi: 10.1097/GME.0000000000000125

28. Sapir-Koren R, Livshits G. Rheumatoid arthritis onset in postmenopausal women: does the ACPA seropositive subset result from genetic effects, estrogen deficiency, skewed profile of CD4+ T-cells, and their interactions? Mol Cell Endocrinol. (2016) 431:145-63. doi: 10.1016/j.mce.2016.05.009

29. Farage MA, Miller KW, Maibach HI. Skin, Mucosa and Menopause. Berlin: Springer-Verlag (2016).

30. Chen Y, Zhang Y, Zhao G, Chen C, Yang P, Ye S, et al. Difference in leukocyte composition between women before and after 
menopausal age, and distinct sexual dimorphism. PLoS ONE. (2016) 11:e0162953. doi: 10.1371/journal.pone.0162953

31. Whitacre CC. Sex differences in autoimmune disease. Nat Immunol. (2001) 2:777-80. doi: 10.1038/ni0901-777

32. Voskuhl RR, Gold SM. Sex-related factors in multiple sclerosis susceptibility and progression. Nat Rev Neurol. (2012) 8:25563. doi: 10.1038/nrneurol.2012.43

33. Belman AL, Krupp LB, Olsen CS, Rose JW, Aaen G, Benson L, et al. Characteristics of children and adolescents with multiple sclerosis. Pediatrics. (2016) 138:e20160120. doi: 10.1542/peds.2016-0120

34. Alonso A, Hernan MA. Temporal trends in the incidence of multiple sclerosis: a systematic review. Neurology. (2008) 71:129-35. doi: 10.1212/01.wnl.0000316802.35974.34

35. Confavreux C, Aimard G, Devic M. Course and prognosis of multiple sclerosis assessed by the computerized data processing of 349 patients. Brain .1980) 103:281-300. doi: 10.1093/brain/103.2.281

36. Alonso A, Jick SS, Olek MJ, Hernan MA. Incidence of multiple sclerosis in the United Kingdom: findings from a population-based cohort. J Neurol. (2007) 254:1736-41. doi: 10.1007/s00415-007-0602-z

37. Grytten N, Glad SB, Aarseth JH, Nyland H, Midgard R, Myhr KM. A 50-year follow-up of the incidence of multiple sclerosis in Hordaland County, Norway. Neurology. (2006) 66:182-6. doi: 10.1212/01.wnl.0000195549.95448.b9

38. Orton SM, Herrera BM, Yee IM, Valdar W, Ramagopalan SV, Sadovnick AD, et al. Sex ratio of multiple sclerosis in Canada: a longitudinal study. Lancet Neurol. (2006) 5:932-6. doi: 10.1016/S1474-4422(06)70581-6

39. Sadovnick AD. European charcot foundation lecture: the natural history of multiple sclerosis and gender. J Neurol Sci. (2009) 286:1-5. doi: 10.1016/j.jns.2009.09.005

40. Maghzi AH, Ghazavi H, Ahsan M, Etemadifar M, Mousavi S, Khorvash $\mathrm{F}$, et al. Increasing female preponderance of multiple sclerosis in Isfahan, Iran: a population-based study. Mult Scler. (2010) 16:35961. doi: 10.1177/1352458509358092

41. Wallin MT, Culpepper WJ, Coffman P, Pulaski S, Maloni H, Mahan CM, et al. The Gulf War era multiple sclerosis cohort: age and incidence rates by race, sex and service. Brain. (2012) 135(Pt 6):1778-85. doi: 10.1093/brain/aws099.

42. Bove R, Healy BC, Secor E, Vaughan T, Katic B, Chitnis T, et al. Patients report worse MS symptoms after menopause: findings from an online cohort. Mult Scler Relat Disord. (2015) 4:18-24. doi: 10.1016/j.msard.2014.11.009

43. Duquette P, Murray TJ, Pleines J, Ebers GC, Sadovnick D, Weldon P, et al. Multiple sclerosis in childhood: clinical profile in 125 patients. J Pediatr. (1987) 111:359-63. doi: 10.1016/S0022-3476(87)80454-7

44. Chitnis T, Glanz B, Jaffin S, Healy B. Demographics of pediatric-onset multiple sclerosis in an MS center population from the Northeastern United States. Mult Scler. (2009) 15:627-31. doi: 10.1177/1352458508101933

45. Ghezzi A, Deplano V, Faroni J, Grasso M, Liguori M, Marrosu G, et al. Multiple sclerosis in childhood: clinical features of 149 cases. Mult Scler. (1997) 3:43-6. doi: 10.1177/135245859700300105

46. Bove RM, Healy B, Augustine A, Musallam A, Gholipour T, Chitnis T. Effect of gender on late-onset multiple sclerosis. Mult Scler. (2012) 18:14729. doi: $10.1177 / 1352458512438236$

47. Pohl D, Hennemuth I, Von Kries R, Hanefeld F. Paediatric multiple sclerosis and acute disseminated encephalomyelitis in Germany: results of a nationwide survey. Eur J Pediatr. (2007) 166:405-12. doi: 10.1007/s00431-006-0249-2

48. Banwell B, Kennedy J, Sadovnick D, Arnold DL, Magalhaes S, Wambera K, et al. Incidence of acquired demyelination of the CNS in Canadian children. Neurology. (2009) 72:232-9. doi: 10.1212/01.wnl.0000339482.84392.bd

49. Dunn S, Lee H, Pavri F, Zhang M. Sex-Based Differences in Multiple Sclerosis (Part I): Biology of Disease Incidence. Berlin: Springer (2015). p. 1-28.

50. Defresne P, Hollenberg H, Husson B, Tabarki B, Landrieu P, Huault G, et al. Acute transverse myelitis in children: clinical course and prognostic factors. J Child Neurol. (2003) 18:401-6. doi: 10.1177/08830738030180060601

51. Leake JAD, Albani S, Kao AS, Senac MO, Billman GF, Nespeca MP, et al. Acute disseminated encephalomyelitis in childhood: epidemiologic, clinical and laboratory features. Pediatr Infect Dis J. (2004) 23:756-64. doi: 10.1097/01.inf.0000133048.75452.dd
52. Ahn JJ, O’Mahony J, Moshkova M, Hanwell HE, Singh H, Zhang MA, et al. Puberty in females enhances the risk of an outcome of multiple sclerosis in children and the development of central nervous system autoimmunity in mice. Mul Scler J. (2015) 21:735-48. doi: 10.1177/1352458514551453

53. Lulu S, Graves J, Waubant E. Menarche increases relapse risk in pediatric multiple sclerosis. Mult Scler. (2015) 22:193-200. doi: $10.1177 / 1352458515581873$

54. Ramagopalan SV, Valdar W, Criscuoli M, DeLuca GC, Dyment DA, Orton SM, et al. Age of puberty and the risk of multiple sclerosis: a population based study. Eur J Neurol. (2009) 16:342-7. doi: 10.1111/j.1468-1331.2008.02431.x

55. Finkelsztejn A, Brooks JB, Paschoal FM Jr, Fragoso YD. What can we really tell women with multiple sclerosis regarding pregnancy? A systematic review and meta-analysis of the literature. BJOG. (2011) 118:7907. doi: 10.1111/j.1471-0528.2011.02931.x

56. Runmarker B, Andersen O. Pregnancy is associated with a lower risk of onset and a better prognosis in multiple sclerosis. BRAIN. (1995) 118:25361. doi: 10.1093/brain/118.1.253

57. Vegeto E, Benedusi V, Maggi A. Estrogen anti-inflammatory activity in brain: a therapeutic opportunity for menopause and neurodegenerative diseases. Front Neuroendocrinol. (2008) 29:507-19. doi: 10.1016/j.yfrne.2008.04.001

58. Airas L. Hormonal and gender-related immune changes in multiple sclerosis. Acta Neurol Scand. (2015) 132:62-70. doi: 10.1111/ane.12433

59. Smith R, Studd JWW. A pilot study of the effect upon multiple sclerosis of the menopause, hormone replacement therapy and the menstrual cycle. $J R$ Soc Med. (1992) 85:612-3.

60. Vukusic S, Hutchinson M, Hours M, Moreau T, Cortinovis-Tourniaire $\mathrm{P}$, Adeleine $\mathrm{P}$, et al. Pregnancy and multiple sclerosis (the PRIMS study): clinical predictors of post-partum relapse. Brain. (2004) 127:135360. doi: 10.1093/brain/awh152

61. Chruzander C, Johansson S, Gottberg K, Einarsson U, Fredrikson S, Holmqvist LW, et al. A 10-year follow-up of a population-based study of people with multiple sclerosis in Stockholm, Sweden: Changes in disability and the value of different factors in predicting disability and mortality. $J$ Neurol Sci. (2013) 332:121-7. doi: 10.1016/j.jns.2013.07.003

62. Abramsky O. Pregnancy and multiple sclerosis. Ann Neurol. (1994) 36:S3841. doi: 10.1002/ana.410360712

63. Confavreux C, Hutchinson M, Hours MM, Cortinovis-Tourniaire P, Moreau T. Rate of pregnancy-related relapse in multiple sclerosis. $N$ Engl J Med. (1998) 339:285-91. doi: 10.1056/NEJM199807303390501

64. McCombe PA, Greer JM. Female reproductive issues in multiple sclerosis. Mult Scler J. (2013) 19:392-402. doi: 10.1177/1352458512452331

65. Magyari M. Role of socio-economic and reproductive factors in the risk of multiple sclerosis. Acta Neurol Scand. (2015) 132:20-3. doi: 10.1111/ane.12426

66. Mackenzie IS, Morant SV, Bloomfield GA, MacDonald TM, O’Riordan J. Incidence and prevalence of multiple sclerosis in the UK 1990-2010: a descriptive study in the General Practice Research Database. J Neurol Neurosurg Psychiatry. (2014) 85:76-84. doi: 10.1136/jnnp-2013-305450

67. Delalande S, De JS, Ferriby D, Stojkovic T, Vermersch P. Late onset multiple sclerosis. Rev Neurol. (2002) 158:1082-7. Available online at: https://www. em-consulte.com/article/104425/alertePM

68. De Seze J, Stojkovic T, Ferriby D, Gauvrit JY, Montagne C, Mounier-Vehier F, et al. Devic's neuromyelitis optica: clinical, laboratory, MRI and outcome profile. J Neurol Sci. (2002) 197:57-61. doi: 10.1016/S0022-510X(02) 00043-6

69. Hawkins S, McDonnell G. Benign multiple sclerosis? Clinical course, long term follow up, and assessment of prognostic factors. J Neurol Neurosurg Psychiatry. (1999) 67:148-52. doi: 10.1136/jnnp.67.2.148

70. Kis B, Rumberg B, Berlit P. Clinical characteristics of patients with late-onset multiple sclerosis. J Neurol. (2008) 255:697702. doi: 10.1007/s00415-008-0778-x

71. Bove R, Chitnis T, Houtchens M. Menopause in multiple sclerosis: therapeutic considerations. J Neurol. (2014) 261:125768. doi: 10.1007/s00415-013-7131-8

72. Christianson MS, Mensah VA, Shen W. Multiple sclerosis at menopause: potential neuroprotective effects of estrogen. Maturitas. (2015) 80:1339. doi: 10.1016/j.maturitas.2014.11.013 
73. Kajta M, Beyer C. Cellular strategies of estrogen-mediated neuroprotection during brain development. Endocrine. (2003) 21:3-9. doi: 10.1385/ENDO:21:1:3

74. Brinton RD. The healthy cell bias of estrogen action: mitochondrial bioenergetics and neurological implications. Trends Neurosci. (2008) 31:52937. doi: 10.1016/j.tins.2008.07.003

75. Filippi M, Wolinsky JS, Sormani MP, Comi G. Enhancement frequency decreases with increasing age in relapsing-remitting multiple sclerosis. Neurology. (2001) 56:422-3. doi: 10.1212/WNL.56.3.422

76. Noseworthy J, Paty D, Wonnacott T, Feasby T, Ebers G. Multiple sclerosis after age 50. Neurology. (1983) 33:1537-44. doi: 10.1212/WNL.33.12.1537

77. Tremlett $H$, Devonshire V. Is late-onset multiple sclerosis associated with a worse outcome? Neurology. (2006) 67:9549. doi: 10.1212/01.wnl.0000237475.01655.9d

78. Hooge JP, Redekop WA. Multiple sclerosis with very late onset. Neurology. (1992) 42:1907-10. doi: 10.1212/WNL.42.10.1907

79. Jarukitsopa S, Hoganson DD, Crowson CS, Sokumbi O, Davis MD, Michet CJ $\mathrm{Jr}$, et al. Epidemiology of systemic lupus erythematosus and cutaneous lupus erythematosus in a predominantly white population in the United States. Arthritis Care Res. (2015) 67:817-28. doi: 10.1002/acr.22502

80. Feldman CH, Hiraki LT, Liu J, Fischer MA, Solomon DH, Alarcon GS, et al. Epidemiology and sociodemographics of systemic lupus erythematosus and lupus nephritis among US adults with Medicaid coverage, 2000-2004. Arthritis Rheum. (2013) 65:753-63. doi: 10.1002/art.37795

81. Somers EC, Marder W, Cagnoli P, Lewis EE, DeGuire P, Gordon C, et al. Population-based incidence and prevalence of systemic lupus erythematosus: the Michigan Lupus Epidemiology and Surveillance program. Arthritis Rheumatol. (2014) 66:369-78. doi: 10.1002/art.38238

82. Gold EB, Bromberger J, Crawford S, Samuels S, Greendale GA, Harlow $\mathrm{SD}$, et al. Factors associated with age at natural menopause in a multiethnic sample of midlife women. Am J Epidemiol. (2001) 153:86574. doi: 10.1093/aje/153.9.865

83. Hill P, Wynder EL, Helman P, Hickman R, Rona G, Kuno K. Plasma hormone levels in different ethnic populations of women. Cancer Res. (1976) 36:2297-301.

84. Pierdominici M, Ortona E. Estrogen impact on autoimmunity onset and progression: the paradigm of systemic lupus erythematosus. Int Trends Immun. (2013) 1:24-34.

85. Ohta A, Nagai M, Nishina M, Tomimitsu H, Kohsaka H. Age at onset and gender distribution of systemic lupus erythematosus, polymyositis/dermatomyositis, and systemic sclerosis in Japan. Modern rheumatology/the Japan Rheumatism Association (2013) 23:759-64. doi: 10.1007/s10165-012-0733-7

86. Whitacre CC, Reingold SC, O'Looney PA, Blankenhorn E, Brinley F, Collier E, et al. A gender gap in autoimmunity: task force on gender, multiple sclerosis and autoimmunity*. Science. (1999) 283:12778. doi: 10.1126/science.283.5406.1277

87. Murphy G, Isenberg D. Effect of gender on clinical presentation in systemic lupus erythematosus. Rheumatology. (2013) 52:210815. doi: 10.1093/rheumatology/ket160

88. Huang JL, Yao TC, See LC. Prevalence of pediatric systemic lupus erythematosus and juvenile chronic arthritis in a Chinese population: a nation-wide prospective population-based study in Taiwan. Clin Exp Rheumatol. (2004) 22:776-80. doi: 10.1016/j.jaut.2012.12.006

89. Wu W. Relationship of age at menarche to body height, weight, and body mass index in Taipei schoolgirls. Taipei City Med J. (2005) 2:e106.

90. Sperotto F, Cuffaro G, Brachi S, Seguso M, Zulian F. Prevalence of antinuclear antibodies in schoolchildren during puberty and possible relationship with musculoskeletal pain: a longitudinal study. J Rheumatol. (2014) 41:14058. doi: 10.3899/jrheum.130948

91. Dickey BZ, Holland KE, Drolet BA, Galbraith SS, Lyon VB, Siegel DH, et al. Demographic and clinical characteristics of cutaneous lupus erythematosus at a paediatric dermatology referral centre. Br J Dermatol. (2013) 169:42833. doi: $10.1111 /$ bjd. 12383

92. Rygg M, Pistorio A, Ravelli A, Maghnie M, Di Iorgi N, Bader-Meunier $\mathrm{B}$, et al. A longitudinal PRINTO study on growth and puberty in juvenile systemic lupus erythematosus. Ann Rheum Dis. (2012) 71:5117. doi: 10.1136/annrheumdis-2011-200106
93. Medeiros P, Febrônio M, Bonfá E, Borba E, Takiuti A, Silva C. Menstrual and hormonal alterations in juvenile systemic lupus erythematosus. Lupus. (2009) 18:38-43. doi: 10.1177/0961203308094652

94. Doria A, Cutolo M, Ghirardello A, Zampieri S, Vescovi F, Sulli A, et al. Steroid hormones and disease activity during pregnancy in systemic lupus erythematosus. Arthritis Care Res. (2002) 47:202-9. doi: 10.1002/art.10248

95. Jara-Quezada L, Graef A, Lavalle C. Prolactin and gonadal hormones during pregnancy in systemic lupus erythematosus. J Rheumatol. (1991) 18:349-53.

96. Walker SE, McMurray RW, Houri JM, Allen SH, Keisler D, Sharp GC, et al. Effects of prolactin in stimulating disease activity in systemic lupus erythematosusa. Ann N Y Acad Sci. (1998) 840:762-72. doi: 10.1111/j.1749-6632.1998.tb09615.x

97. McMurray RW, Allen SH, Braun AL, Rodriguez F, Walker SE. Longstanding hyperprolactinemia associated with systemic lupus erythematosus: possible hormonal stimulation of an autoimmune disease. J Rheumatol. (1994) 21:843-50.

98. Funauchi M, Ikoma S, Enomoto H, Sugiyama M, Ohno M, Hamada K, et al. Prolactin modulates the disease activity of systemic lupus erythematosus accompanied by prolactinoma. Clin Exp Rheumatol. (1998) 16:479-82.

99. Pacilio M, Migliaresi S, Meli R, Ambrosone L, Bigliardo B, Di Carlo R. Elevated bioactive prolactin levels in systemic lupus erythematosusassociation with disease activity. J Rheumatol. (2001) 28:2216-21.

100. Jara LJ, Gomez-Sanchez C, Silveira LH, Martinez-Osuna P, Vasey FB, Espinoza LR. Hyperprolactinemia in systemic lupus erythematosus: association with disease Activity. Am J Med Sci. (1992) 303:2226. doi: 10.1097/00000441-199204000-00003

101. Jara LJ, Medina G, Cruz-Dominguez P, Navarro C, Vera-Lastra O, Saavedra MA. Risk factors of systemic lupus erythematosus flares during pregnancy. Immunol Res. (2014) 60:184-92. doi: 10.1007/s12026-014-8577-1

102. Auml MS, Unnérus HA, Hirvonen E, Ranta T. Bromocriptine increases plasma estradiol-17 $\beta$ concentration in amenorrhea patients with normal serum prolactin. J Clin Endocrinol Metab. (1976) 43:474-7. doi: 10.1210/jcem-43-2-474

103. Walker SE, Reddy GH, Miller D, Yangco D, Kalanje S, Abdou NI, et al. Treatment of active systemic lupus erythematosus (SLE) with the prolactin (PRL) lowering drug, bromocriptine (BC): comparison with hydroxychloroquine (HC) in a randomized, blinded one-year study. Arthritis Rheum. (1999) 42:S282.

104. Alvarez-Nemegyei J, Cobarrubias-Cobos A, Escalante-Triay F, Sosa-Muüoz J, Miranda JM, Jara LJ. Bromocriptine in systemic lupus erythematosus: a double-blind, randomized, placebo-controlled study. Lupus. (1998) 7:4149. doi: 10.1191/096120398678920334

105. Jara LJ, Cruz-Cruz P, Saavedra MA, Medina G, Garcia-Flores A, Angeles U, et al. Bromocriptine during pregnancy in systemic lupus erythematosus: a pilot clinical trial. Ann N Y Acad Sci. (2007) 1110:297304. doi: 10.1196/annals.1423.031

106. Straub RH. The complex role of estrogens in inflammation. Endocr Rev (2007) 28:521-74. doi: 10.1210/er.2007-0001

107. Boddaert J, D.Huong LT, Amoura Z, Wechsler B, Godeau P, Piette JC. Late-onset systemic lupus erythematosus. Medicine. (2004) 83:34859. doi: 10.1097/01.md.0000147737.57861.7c

108. Costenbader KH, Feskanich D, Stampfer MJ, Karlson EW. Reproductive and menopausal factors and risk of systemic lupus erythematosus in women. Arthritis Rheum. (2007) 56:1251-62. doi: 10.1002/art. 22510

109. Mok CC, Lau CS, Ho CTK, Wong RWS. Do flares of systemic lupus erythematosus decline after menopause? Scand J Rheumatol. (1999) 28:35762. doi: 10.1080/03009749950155346

110. Sánchez-Guerrero J, Villegas A, Mendoza-Fuentes A, Romero-Díaz J, Moreno-Coutio G, Cravioto MC. Disease activity during the premenopausal and postmenopausal periods in women with systemic lupus erythematosus. Am J Med. (2001) 111:464-8. doi: 10.1016/S0002-9343(01) 00885-3

111. Fernández M, Calvo-Alén J, Alarcón GS, Roseman JM, Bastian HM, Fessler BJ, et al. Systemic lupus erythematosus in a multiethnic US cohort (LUMINA). XXI. Disease activity, damage accrual, and vascular events in pre- and postmenopausal women. Arthritis Rheum. (2005) 52:165564. doi: 10.1002/art. 21048 
112. Urowitz MB, Iba-ez D, Jerome D, Gladman DD. The effect of menopause on disease activity in systemic lupus erythematosus. J Rheumatol. (2006) 33:2192-8.

113. Atkinson MA, Eisenbarth GS, Michels AW. Type 1 diabetes. Lancet. (2014) 383 69-82. doi: 10.1016/S0140-6736(13)60591-7

114. Patterson C, Guariguata L, Dahlquist G, Soltesz G, Ogle G, Silink M. Diabetes in the young - a global view and worldwide estimates of numbers of children with type 1 diabetes. Diabetes Res Clin Pract. (2014) 103:16175. doi: 10.1016/j.diabres.2013.11.005

115. Harjutsalo V, Sjöberg L, Tuomilehto J. Time trends in the incidence of type 1 diabetes in Finnish children: a cohort study. Lancet. (2008) 371 1777-82. doi: 10.1016/S0140-6736(08)60765-5

116. Nishimura R, Tajima N, Matsushima M, LaPorte RE. Puberty, IDDM, and Death in Japan. Diabetes Care. (1998) 21:16749. doi: 10.2337/diacare.21.10.1674

117. Cho YH, Craig ME, Donaghue KC. Puberty as an accelerator for diabetes complications. Pediatric Diabetes. (2014) 15:18-26. doi: 10.1111/pedi.12112

118. Rosolowsky ET, Skupien J, Smiles AM, Niewczas M, Roshan B, Stanton R, et al. Risk for ESRD in Type 1 diabetes remains high despite renoprotection. J Am Soc Nephrol. (2011) 22:545-53. doi: 10.1681/ASN.2010040354

119. Mollsten A, Svensson M, Waernbaum I, Berhan Y, Schon S, Nystrom $\mathrm{L}$, et al. Cumulative risk, age at onset, and sex-specific differences for developing end-stage renal disease in young patients with type 1 diabetes: a nationwide population-based cohort study. Diabetes. (2010) 59:18038. doi: $10.2337 / \mathrm{db} 09-1744$

120. Gallego PH, Craig ME, Hing S, Donaghue KC. Role of blood pressure in development of early retinopathy in adolescents with type 1 diabetes: prospective cohort study. BMJ. (2008) 337:a918. doi: 10.1136/bmj.a918

121. Lee SI, Patel M, Jones CM, Narendran P. Cardiovascular disease and type 1 diabetes: prevalence, prediction and management in an ageing population. Ther Adv Chronic Dis. (2015) 6:347-74. doi: 10.1177/2040622315 598502

122. Laing SP, Swerdlow AJ, Slater SD, Burden AC, Morris A, Waugh NR, et al. Mortality from heart disease in a cohort of 23,000 patients with insulin-treated diabetes. Diabetologia. (2003) 46:760-5. doi: 10.1007/s00125-003-1116-6

123. Huxley RR, Peters SAE, Mishra GD, Woodward M. Risk of all-cause mortality and vascular events in women versus men with type 1 diabetes: a systematic review and meta-analysis. Lancet Diabetes Endocrinol. (2015) 3:198-206. doi: 10.1016/S2213-8587(14)70248-7

124. Moran A, Jacobs DR, Steinberger J, Hong CP, Prineas R, Luepker R, et al. Insulin resistance during puberty: results from clamp studies in 357 children. Diabetes. (1999) 48:2039-44. doi: 10.2337/diabetes.48.10.2039

125. Rudberg S, Persson B. Serum leptin levels in young females with insulin-dependent diabetes and the relationship to hyperandrogenicity and microalbuminuria. Hormone Res Paediatr. (1998) 50:297302. doi: 10.1159/000023294

126. Cho YH, Craig ME, Srinivasan S, Benitez-Aguirre P, Mitchell $\mathrm{P}$, Jopling $\mathrm{T}$, et al. Heart rate variability in pubertal girls with type 1 diabetes: its relationship with glycaemic control, insulin resistance and hyperandrogenism. Clin Endocrinol. (2014) 80:818-24. doi: 10.1111/cen.12238

127. Hillman N, Herranz L, Vaquero PM, Villarroel A, Fernandez A, Pallardo LF. Is pregnancy outcome worse in type 2 than in type 1 diabetic women? Diabetes Care. (2006) 29:2557-8. doi: 10.2337/dc06-0680

128. Cundy T, Gamble G, Neale L, Elder R, McPherson P, Henley P, et al. Differing causes of pregnancy loss in type 1 and type 2 diabetes. Diabetes Care. (2007) 30:2603-7. doi: 10.2337/dc07-0555

129. Knight KM, Thornburg LL, Pressman EK. Pregnancy outcomes in type 2 diabetic patients as compared with type 1 diabetic patients and nondiabetic controls. J Reprod Med. (2012) 57:397-404.

130. Donovan PJ, McIntyre HD. Drugs for gestational diabetes. Aust Prescriber. (2010) 33:141-4. doi: 10.18773/austprescr.2010.066

131. Mahmoud F, Abul H, Omu A, Haines D. Lymphocyte subpopulations in gestational diabetes. Am J Reprod Immunol. (2005) 53:21-9. doi: 10.1111/j.1600-0897.2004.00241.x

132. Lapolla A, Dalfrà MG, Sanzari M, Fedele D, Betterle C, Masin $M$, et al. Lymphocyte subsets and cytokines in women with gestational diabetes mellitus and their newborn. Cytokine. (2005) 31:280-7. doi: 10.1016/j.cyto.2005.05.004

133. Lapolla A, Sanzari MC, Zancanaro F, Masin M, Guerriero A, Piva I, et al. A study on lymphocyte subpopulation in diabetic mothers at delivery and in their newborn. Diabetes Nutr Metab Clin Exp. (1999) 12:394-9.

134. Lapolla A, Sanzari M, Betterle C, Dalfrà MG, Masin M, Zanchetta R, et al. Evaluation of T-cell receptor $\mathrm{CD} 3+\gamma \delta$ in gestational diabetes mellitus. Acta Diabetol. (2000) 37:207-11. doi: 10.1007/s005920070007

135. Lapolla A, Betterle C, Sanzari M, Zanchetta R, Pfeifer E, Businaro A, et al. An immunological and genetic study of patients with gestational diabetes mellitus. Acta Diabetol. (1996) 33:139-44. doi: 10.1007/BF00569424

136. Mahmoud F, Abul H, Dashti A, Al-Jassar W, Omu A. Trace elements and cell-mediated immunity in gestational and pre-gestational diabetes mellitus at third trimester of pregnancy. Acta Med Acad. (2012) 41:17585. doi: 10.5644/ama2006-124.50

137. Schober L, Radnai D, Spratte J, Kisielewicz A, Schmitt E, Mahnke K, et al. The role of regulatory T cell (Treg) subsets in gestational diabetes mellitus. Clin Exp Immunol. (2014) 177:76-85. doi: 10.1111/cei.12300

138. Yang Y, Li Q, Wang Q, Ma X. Thyroid antibodies and gestational diabetes mellitus: a meta-analysis. Fertil Steril. (2015) 104:665-71 e3. doi: 10.1016/j.fertnstert.2015.06.003

139. Pascual Corrales E, Andrada P, Aubá M, Ruiz Zambrana Á, Guillén Grima F, Salvador J, et al. ¿Existe mayor riesgo de diabetes gestacional en pacientes con disfunción tiroidea autoinmune? Endocrinol Nutrición. (2014) 61:37781. doi: 10.1016/j.endonu.2014.01.009

140. Haller-Kikkatalo K, Uibo R. Clinical recommendations for the use of islet cell autoantibodies to distinguish autoimmune and non-autoimmune gestational diabetes. Clin Rev Allergy Immunol. (2016) 50:23-33. doi: 10.1007/s12016-014-8461-8

141. Öztekin Ö. New insights into the pathophysiology of gestational diabetes mellitus: possible role of human leukocyte antigen-G. Med Hypotheses. (2007) 69:526-30. doi: 10.1016/j.mehy.2007.01.054

142. Vejrazkova D, Vcelak J, Vankova M, Lukasova P, Bradnova O, Halkova T, et al. Steroids and insulin resistance in pregnancy. J Steroid Biochem Mol Biol. (2014) 139:122-9. doi: 10.1016/j.jsbmb.2012.11.007

143. Barbour LA, McCurdy CE, Hernandez TL, Kirwan JP, Catalano PM, Friedman JE. Cellular mechanisms for insulin resistance in normal pregnancy and gestational diabetes. Diabetes Care. (2007) 30:S1129. doi: $10.2337 / \mathrm{dc} 07-\mathrm{s} 202$

144. Thadhani R, Wolf M, Hsu-Blatman K, Sandler L, Nathan D, Ecker JL. Firsttrimester sex hormone binding globulin and subsequent gestational diabetes mellitus. Am J Obstetr Gynecol. (2003) 189:171-6. doi: 10.1067/mob.2003.343

145. Järvelä IY, Juutinen J, Koskela P, Hartikainen AL, Kulmala P, Knip M, et al. Gestational diabetes identifies women at risk for permanent type 1 and type 2 diabetes in fertile age: predictive role of autoantibodies. Diabetes Care. (2006) 29:607-12. doi: 10.2337/diacare.29.03.06.dc05-1118

146. Olivieri A, Valensise H, Magnani F, Medda E, De Angelis S, D’Archivio $\mathrm{M}$, et al. High frequency of antithyroid autoantibodies in pregnant women at increased risk of gestational diabetes mellitus. Eur J Endocrinol. (2000) 143:741-7. doi: 10.1530/eje.0.1430741

147. Weetman AP. Immunity, thyroid function and pregnancy: molecular mechanisms. Nat Rev Endocrinol. (2010) 6:3118. doi: $10.1038 /$ nrendo.2010.46

148. Karakosta P, Alegakis D, Georgiou V, Roumeliotaki T, Fthenou E, Vassilaki M, et al. Thyroid dysfunction and autoantibodies in early pregnancy are associated with increased risk of gestational diabetes and adverse birth outcomes. J Clin Endocrinol Metab. (2012) 97:446472. doi: 10.1210/jc.2012-2540

149. Agarwal MM, Dhatt GS, Punnose J, Bishawi B, Zayed R. Thyroid function abnormalities and antithyroid antibody prevalence in pregnant women at high risk for gestational diabetes mellitus. Gynecol Endocrinol. (2006) 22:261-6. doi: 10.1080/09513590600630470

150. Sjöberg L, Pitkäniemi J, Harjutsalo V, Haapala L, Tiitinen A, Tuomilehto $\mathrm{J}$, et al. Menopause in women with type 1 diabetes. Menopause. (2011) 18:158-63. doi: 10.1097/gme.0b013e3181ef3af0

151. Dorman JS, Steenkiste AR, Foley TP, Strotmeyer ES, Burke JP, Kuller LH, et al. Menopause in type 1 diabetic women: is it premature? Diabetes. (2001) 50:1857-62. doi: 10.2337/diabetes.50.8.1857 
152. Woodward M, Huxley RR. Increased risk of coronary heart disease in female smokers - Authors' reply. Lancet. (2012) 379:803. doi: 10.1016/S0140-6736(12)60346-8

153. Huxley R, Barzi F, Woodward M. Excess risk of fatal coronary heart disease associated with diabetes in men and women: meta-analysis of 37 prospective cohort studies. BMJ. (2006) 332:73-8. doi: 10.1136/bmj.38678.389583.7C

154. Kim H, Elmi A, Henderson CL, Cogen FR, Kaplowitz PB. Characteristics of Children with type 1 diabetes and persistent suboptimal glycemic control. $J$ Clin Res Pediatr Endocrinol. (2012) 4:82-8. doi: 10.4274/Jcrpe.663

155. Petitti DB, Klingensmith GJ, Bell RA, Andrews JS, Dabelea D, Imperatore G, et al. Glycemic control in youth with diabetes: the search for diabetes in youth study. J Pediatr. (2009) 155:668-72 e3. doi: 10.1016/j.jpeds.2009.05.025

156. Amiel SA, Sherwin RS, Simonson DC, Lauritano AA, Tamborlane WV. Impaired insulin action in puberty. $N$ Engl J Med. (1986) 315:2159. doi: 10.1056/NEJM198607243150402

157. Bloch CA, Clemons P, Sperling MA. Puberty decreases insulin sensitivity. J Pediatr. (1987) 110:481-7. doi: 10.1016/S0022-3476(87)80522-X

158. Arrais RF, Dib SA. The hypothalamus-pituitary-ovary axis and type 1 diabetes mellitus: a mini review. Hum Reprod. (2006) 21:32737. doi: 10.1093/humrep/dei353

159. Goemaere S, Ackerman C, Goethals K, De Keyser F, Van Der Straeten C, Verbruggen $\mathrm{G}$, et al. Onset of symptoms of rheumatoid arthritis in relation to age, sex and menopausal transition. J Rheumatol. (1990) 17:1620-2.

160. Da Silva JAP, Hall GM. The effects of gender and sex hormones on outcome in rheumatoid arthritis. Baillière's Clin Rheumatol. (1992) 6:193219. doi: 10.1016/S0950-3579(05)80344-9

161. Kuo CF, Luo SF, See LC, Chou IJ, Chang HC, Yu KH. Rheumatoid arthritis prevalence, incidence, and mortality rates: a nationwide population study in Taiwan. Rheumatol Int. (2013) 33:355-60. doi: 10.1007/s00296-012-2411-7

162. Rudan I, Sidhu S, Papana A, Meng SJ, Xin-Wei Y, Wang W, et al. Prevalence of rheumatoid arthritis in low- and middle-income countries: a systematic review and analysis. J Glob Health. (2015) 5:010409. doi: 10.7189/jogh.05.010409

163. Cutolo M, Sulli A, Capellino S, Villaggio B, Montagna P, Seriolo B, et al. Sex hormones influence on the immune system: basic and clinical aspects in autoimmunity. Lupus. (2004) 13:635-8. doi: 10.1191/0961203304lu1094oa

164. Castagnetta LA, Carruba G, Granata OM, Stefano R, Miele M, Schmidt $\mathrm{M}$, et al. Increased estrogen formation and estrogen to androgen ratio in the synovial fluid of patients with rheumatoid arthritis. J Rheumatol. (2003) 30:2597-605.

165. Chiaroni-Clarke RC, Li YR, Munro JE, Chavez RA, Scurrah KJ, Pezic A, et al. The association of PTPN22 rs2476601 with juvenile idiopathic arthritis is specific to females. Genes Immun. (2015) 16:4958. doi: 10.1038 /gene. 2015.32

166. Pikwer M, Bergström U, Nilsson JÅ, Jacobsson L, Turesson C. Early menopause is an independent predictor of rheumatoid arthritis. Ann Rheum Dis. (2012) 71:378-81. doi: 10.1136/ard.2011.200059

167. Pedersen M, Jacobsen S, Klarlund M, Pedersen BV, Wiik A, Wohlfahrt J, et al. Environmental risk factors differ between rheumatoid arthritis with and without auto-antibodies against cyclic citrullinated peptides. Arthritis Res Ther. (2006) 8:R133. doi: 10.1186/ar2022

168. Avila MH, Liang MH, Willett WC, Stampfer MJ, Colditz GA, Rosner B, et al. Reproductive factors, smoking, and the risk for rheumatoid arthritis. Epidemiology. (1990) 1:285-91. doi: 10.1097/00001648-199007000-0 0005

169. Maher S, Ali F. Sexual maturation in Egyptian boys and girls with juvenile rheumatoid arthritis. Rheumatol Int. (2013) 33:2123-6. doi: 10.1007/s00296-013-2683-6

170. Hazes JMW, Dijkmans BAC, Vandenbroucke JP, Vries RRPD, Cats A. Pregnancy and the risk of developing rheumatoid arthritis. Arthritis Rheum. (1990) 33:1770-5. doi: 10.1002/art.1780331203

171. Pikwer M, Bergström U, Nilsson JÅ, Jacobsson L, Berglund G, Turesson C. Breast feeding, but not use of oral contraceptives, is associated with a reduced risk of rheumatoid arthritis. Ann Rheum Dis. (2009) 68:52630. doi: 10.1136/ard.2007.084707

172. Brun JG, Nilssen S, Kvåle G. Breast feeding, other reproductive factors and rheumatoid arthritis. A prospective study. Rheumatology. (1995) 34:5426. doi: 10.1093/rheumatology/34.6.542
173. Karlson EW, Mandl LA, Hankinson SE, Grodstein F. Do breast-feeding and other reproductive factors influence future risk of rheumatoid arthritis? Results from the Nurses' Health Study. Arthritis Rheum. (2004) 50:345867. doi: 10.1002/art.20621

174. Adab P, Jiang CQ, Rankin E, Tsang YW, Lam TH, Barlow J, et al. Breastfeeding practice, oral contraceptive use and risk of rheumatoid arthritis among Chinese women: the Guangzhou Biobank Cohort Study. Rheumatology. (2014) 53:860-6. doi: 10.1093/rheumatology/ket456

175. Lankarani-Fard A, Kritz-Silverstein D, Barrett-Connor E, Goodman-Gruen D. Cumulative duration of breast-feeding influences cortisol levels in postmenopausal women. J Women's Health Gender Based Med. (2001) 10:681-7. doi: 10.1089/15246090152563560

176. Drossaers-Bakker K, Zwinderman A, van Zeben D, Breedveld F, Hazes J. Pregnancy and oral contraceptive use do not significantly influence outcome in long term rheumatoid arthritis. Ann Rheum Dis. (2002) 61:4058. doi: 10.1136/ard.61.5.405

177. Heinrichs M, Baumgartner T, Kirschbaum C, Ehlert U. Social support and oxytocin interact to suppress cortisol and subjective responses to psychosocial stress. Biol Psychiatry. (2003) 54:138998. doi: 10.1016/S0006-3223(03)00465-7

178. Gutkowska J, Jankowski M, Mukaddam-Daher S, McCann S. Oxytocin is a cardiovascular hormone. Braz J Med Biol Res. (2000) 33:62533. doi: 10.1590/S0100-879X2000000600003

179. McMurray RW. Estrogen, prolactin, and autoimmunity: actions and interactions. Int Immunopharmacol. (2001) 1:9951008. doi: 10.1016/S1567-5769(01)00045-5

180. Chikanza I, Petrou P, Chrousos G, Kingsley G, Panayi G. Excessive and dysregulated secretion of prolactin in rheumatoid arthritis: immunopathogenetic and therapeutic implications. Rheumatology. (1993) 32:445-8. doi: 10.1093/rheumatology/32.6.445

181. Zoli A, Lizzio MM, Ferlisi EM, Massafra V, Mirone L, Barini A, et al. ACTH, cortisol and prolactin in active rheumatoid arthritis. Clin Rheumatol. (2002) 21:289-93. doi: 10.1007/s100670200076

182. Beydoun HA, el-Amin R, McNeal M, Perry C, Archer DF. Reproductive history and postmenopausal rheumatoid arthritis among women 60 years or older: third national health and nutrition examination survey. Menopause. (2013) 20:930-5. doi: 10.1097/GME.0b013e3182a14372

183. Merlino LA, Cerhan JR, Criswell LA, Mikuls TR, Saag KG. Estrogen and other female reproductive risk factors are not strongly associated with the development of rheumatoid arthritis in elderly women. Semin Arthritis Rheum. (2003) 33:72-82. doi: 10.1016/S0049-0172(03)00084-2

184. Wong LE, Huang WT, Pope JE, Haraoui B, Boire G, Thorne JC, et al. Effect of age at menopause on disease presentation in early rheumatoid arthritis: results from the Canadian early arthritis cohort. Arthritis Care Res. (2015) 67:616-23. doi: 10.1002/acr.22494

185. Alpizar-Rodriguez D, Förger F, Courvoisier DS, Gabay C, Finckh A. Role of reproductive and menopausal factors in functional and structural progression of rheumatoid arthritis: results from the SCQM cohort. Rheumatology. (2019) 58:432-40. doi: 10.1093/rheumatology/key311

186. Mollard E, Pedro S, Chakravarty E, Clowse M, Schumacher $\mathrm{R}$, Michaud $\mathrm{K}$. The impact of menopause on functional status in women with rheumatoid arthritis. Rheumatology. (2018) 57:798-802. doi: 10.1093/rheumatology/kex526

187. Kuiper S, van Gestel AM, Swinkels HL, de Boo TM, da Silva JA, van Riel PL. Influence of sex, age, and menopausal state on the course of early rheumatoid arthritis. J Rheumatol. (2001) 28:1809-16.

188. Orellana C, Saevarsdottir S, Klareskog L, Karlson EW, Alfredsson L, Bengtsson C. Postmenopausal hormone therapy and the risk of rheumatoid arthritis: results from the Swedish EIRA population-based case-control study. Eur J Epidemiol. (2015) 30:449-57. doi: 10.1007/s10654-0150004-y

189. Icen M, Crowson CS, McEvoy MT, Dann FJ, Gabriel SE, Maradit Kremers H. Trends in incidence of adult-onset psoriasis over three decades: a population-based study. J Am Acad Dermatol. (2009) 60:394401. doi: 10.1016/j.jaad.2008.10.062

190. Huerta C, Rivero E, García Rodríguez LA. Incidence and risk factors for psoriasis in the general population. Arch Dermatol. (2007) 143:155965. doi: 10.1001/archderm.143.12.1559 
191. Wilson FC, Icen M, Crowson CS, McEvoy MT, Gabriel SE, Kremers HM. Time trends in epidemiology and characteristics of psoriatic arthritis over 3 decades: a population-based study. J Rheumatol. (2009) 36:3617. doi: 10.3899/jrheum.080691

192. Swanbeck G, Inerot A, Martinsson T, Wahlstrom J, Enerback C, Enlund F, et al. Age at onset and different types of psoriasis. Br J Dermatol. (1995) 133:768-73. doi: 10.1111/j.1365-2133.1995.tb02753.x

193. Henseler T, Christophers E. Psoriasis of early and late onset: characterization of two types of psoriasis vulgaris. J Am Acad Dermatol. (1985) 13:4506. doi: 10.1016/S0190-9622(85)70188-0

194. Burch PR, Rowell NR. Psoriasis: aetiological aspects. Acta Derm Venereol. (1965) 45:366-80.

195. Verdier-Sevrain S, Yaar M, Cantatore J, Traish A, Gilchrest BA. Estradiol induces proliferation of keratinocytes via a receptor mediated mechanism. FASEB J. (2004) 18:1252-4. doi: 10.1096/fj.03-1088fje

196. Cutolo M, Brizzolara R, Atzeni F, Capellino S, Straub RH, Puttini PC. The immunomodulatory effects of estrogens: clinical relevance in immune-mediated rheumatic diseases. Ann N Y Acad Sci. (2010) 1193:3642. doi: 10.1111/j.1749-6632.2009.05383.x

197. Verthelyi D. Sex hormones as immunomodulators in health and disease. Int Immunopharmacol. (2001) 1:983-93. doi: 10.1016/S1567-5769(01)00044-3

198. Murase JE, Chan KK, Garite TJ, Cooper DM, Weinstein GD. Hormonal effect on psoriasis in pregnancy and post partum. Arch Dermatol. (2005) 141:601-6. doi: 10.1001/archderm.141.5.601

199. Farber EM, Nall ML. The natural history of psoriasis in 5,600 patients. Dermatology. (1974) 148:1-18. doi: 10.1159/000251595

200. Oumeish OY, Al-Fouzan AWS. Miscellaneous diseases affected by pregnancy. Clin Dermatol. (2006) 24:1137. doi: 10.1016/j.clindermatol.2005.10.003

201. Boyd AS, Morris LF, Phillips CM, Menter MA. Psoriasis and pregnancy: hormone and immune system interaction. Int J Dermatol. (1996) 35:16972. doi: 10.1111/j.1365-4362.1996.tb01632.x

202. McNeill ME. Multiple pregnancy-induced remissions of psoriatic arthritis: case report. Am J Obstetr Gynecol. (1988) 159:8967. doi: 10.1016/S0002-9378(88)80165-0

203. Kanda N, Watanabe S. Regulatory roles of sex hormones in cutaneous biology and immunology. J Dermatol Sci. (2005) 38:1-7. doi: 10.1016/j.jdermsci.2004.10.011

204. Ceovic R, Mance M, Bukvic Mokos Z, Svetec M, Kostovic K, Stulhofer Buzina D. Psoriasis: female skin changes in various hormonal stages throughout life-puberty, pregnancy, and menopause. BioMed Res Int. (2013) 2013:571912. doi: 10.1155/2013/571912

205. Vaseghi H, Jadali Z. Th1/Th2 cytokines in Type 1 diabetes: relation to duration of disease and gender. Indian J Endocrinol Metab. (2016) 20:3126. doi: 10.4103/2230-8210.180002

206. Makino S, Kunimoto K, Muraoka Y, Katagiri K. Effect of castration on the appearance of diabetes in NOD mouse. Jikken Dobutsu. (1981) 30:13740. doi: 10.1538/expanim1978.30.2_137

207. Lamason R, Zhao P, Rawat R, Davis A, Hall JC, Chae JJ, et al. Sexual dimorphism in immune response genes as a function of puberty. BMC Immunol. (2006) 7:2. doi: 10.1186/1471-2172-7-2

208. Kautzky-Willer A. Sex and gender differences in endocrinology. In: OerteltPrigione S, Regitz-Zagrosek V, editors. Sex and Gender Aspects in Clinical Medicine. London: Springer (2012). p. 125-49.

209. Geisler JG, Zawalich W, Zawalich K, Lakey JR, Stukenbrok H, Milici AJ, et al. Estrogen can prevent or reverse obesity and diabetes in mice expressing human islet amyloid polypeptide. Diabetes. (2002) 51:215869. doi: 10.2337/diabetes.51.7.2158

210. Zhao HL, Sui Y, Guan J, He L, Lai FM, Zhong DR, et al. Higher islet amyloid load in men than in women with type 2 diabetes mellitus. Pancreas. (2008) 37:e68-73. doi: 10.1097/MPA.0b013e3181788e18

211. Pozzilli P, Mesturino CA, Crino A, Gross TM, Jeng LM, Visalli N, et al. Is the process of beta-cell destruction in type 1 diabetes at time of diagnosis more extensive in females than in males? Eur J Endocrinol. (2001) 145:75761. doi: 10.1530/eje.0.1450757

212. Gillespie KM, Nolsoe R, Betin VM, Kristiansen OP, Bingley PJ, MandrupPoulsen T, et al. Is puberty an accelerator of type 1 diabetes in IL6-174CC females? Diabetes. (2005) 54:1245-8. doi: 10.2337/diabetes.54.4.1245
213. Harrison LC, Honeyman MC, Morahan G, Wentworth JM, Elkassaby S, Colman PG, Fourlanos S. Type 1 diabetes: lessons for other autoimmune diseases? J Autoimmun. (2008) 31:306-10. doi: 10.1016/j.jaut.200 8.04 .026

214. Yu L, Chase HP, Falorni A, Rewers M, Lernmark A, Eisenbarth GS. Sexual dimorphism in transmission of expression of islet autoantibodies to offspring. Diabetologia. (1995) 38:1353-7. doi: 10.1007/BF00401769

215. Wengreen H, Cutler DR, Munger R, Willing M. Vitamin D receptor genotype and risk of osteoporotic hip fracture in elderly women of Utah: an effect modified by parity. Osteoporos Int. (2006) 17:114653. doi: 10.1007/s00198-006-0100-7

216. Yao G, Liang J, Han $\mathrm{X}$, Hou Y. In vivo modulation of the circulating lymphocyte subsets and monocytes by androgen. Int Immunopharmacol. (2003) 3:1853-60. doi: 10.1016/j.intimp.2003.09.002

217. Tomassini V, Onesti E, Mainero C, Giugni E, Paolillo A, Salvetti $\mathrm{M}$, et al. Sex hormones modulate brain damage in multiple sclerosis: MRI evidence. J Neurol Neurosurg Psychiatry. (2005) 76:272-5. doi: 10.1136/jnnp.2003.033324

218. Maret A, Coudert JD, Garidou L, Foucras G, Gourdy P, Krust A, et al. Estradiol enhances primary antigen-specific CD4 $\mathrm{T}$ cell responses and Th1 development in vivo. Essential role of estrogen receptor $\alpha$ expression in hematopoietic cells. Eur J Immunol. (2003) 33:51221. doi: 10.1002/immu.200310027

219. Laffont S, Garnier L, Lelu K, Guery JC. Estrogen-mediated protection of experimental autoimmune encephalomyelitis: Lessons from the dissection of estrogen receptor-signaling in vivo. Biomed J. (2015) 38:194-205. doi: 10.4103/2319-4170.158509

220. Kovats S. Estrogen receptors regulate innate immune cells and signaling pathways. Cell Immunol. (2015) 294:639. doi: 10.1016/j.cellimm.2015.01.018

221. Holmqvist P, Wallberg M, Hammar M, Landtblom AM, Brynhildsen J. Symptoms of multiple sclerosis in women in relation to sex steroid exposure. Maturitas. (2006) 54:149-53. doi: 10.1016/j.maturitas.2005.10.003

222. Rider V, Abdou NI. Gender differences in autoimmunity: molecular basis for estrogen effects in systemic lupus erythematosus. Int Immunopharmacol. (2001) 1:1009-24. doi: 10.1016/S1567-5769(01)00046-7

223. Cohen-Solal J, Jeganathan V, Grimaldi C, Peeva E, Diamond B. Sex Hormones and SLE: Influencing the Fate of Autoreactive B Cells. Springer: Current Concepts in Autoimmunity and Chronic Inflammation. (2006). p. 6788. doi: 10.1007/3-540-29714-6_4

224. Rider V, Abdou NI, Kimler BF, Lu N, Brown S, Fridley BL. Gender bias in human systemic lupus erythematosus: a problem of steroid receptor action? Front Immunol. (2018) 9:611. doi: 10.3389/fimmu.2018. 00611

225. Liu HY, Buenafe AC, Matejuk A, Ito A, Zamora A, Dwyer J, et al. Estrogen inhibition of EAE involves effects on dendritic cell function. J Neurosci Res. (2002) 70:238-48. doi: 10.1002/jnr.10409

226. Correale J, Arias M, Gilmore W. Steroid hormone regulation of cytokine secretion by proteolipid protein-specific CD4+ $\mathrm{T}$ cell clones isolated from multiple sclerosis patients and normal control subjects. J Immunol. (1998) 161:3365-74.

227. Riant E, Bayard F, Arnal JF, Gourdy P, Ohlsson C, Bourgeois EA, et al. Estrogen therapy delays autoimmune diabetes and promotes the protective efficiency of natural killer T-cell activation in female nonobese diabetic mice. Endocrinology. (2016) 157:258-67. doi: 10.1210/en.20151313

228. McMurray RW. Steroid hormones in lupus pregnancy: in control? Arthritis Care Res. (2002) 47:116-7. doi: 10.1002/art.10338

229. Petri M, Howard D, Repke J. Frequency of lupus flare in pregnancy. The Hopkins Lupus Pregnancy Center experience. Arthritis Rheum. (1991) 34:1538-45. doi: 10.1002/art.1780341210

230. Khamashta MA, Ruiz-Irastorza G, Hughes GR. Systemic lupus erythematosus flares during pregnancy. Rheum Dis Clin North Am. (1997) 23:15-30. doi: 10.1016/S0889-857X(05)70312-4

231. McMurray RW. Sex hormones in the pathogenesis of systemic lupus erythematosus. Front Biosci. (2001) 6:E193-206. doi: 10.2741/A708

232. Lahita RG. The role of sex hormones in systemic lupus erythematosus. Curr Opin Rheumatol. (1999) 11:352-6. doi: 10.1097/00002281-199909000-00005 
233. Valor L, Teijeiro R, Aristimuo C, Faure F, Alonso B, de Andrés C, et al. Estradiol-dependent perforin expression by human regulatory T-cells. Eur J Clin Invest. (2011) 41:357-64. doi: 10.1111/j.1365-2362.2010.02414.x

234. Prieto GA, Rosenstein Y. Oestradiol potentiates the suppressive function of human $\mathrm{CD} 4(+) \mathrm{CD} 25(+)$ regulatory $\mathrm{T}$ cells by promoting their proliferation. Immunology. (2006) 118:5865. doi: 10.1111/j.1365-2567.2006.02339.x

235. Abdou NI, Rider V, Greenwell C, Li X, Kimler BF. Fulvestrant (Faslodex), an estrogen selective receptor downregulator, in therapy of women with systemic lupus erythematosus. clinical, serologic, bone density, and $\mathrm{T}$ cell activation marker studies: a double-blind placebo-controlled trial. $J$ Rheumatol. (2008) 35:797.

236. Bove R. Autoimmune diseases and reproductive aging. Clin Immunol. (2013) 149:251-64. doi: 10.1016/j.clim.2013.02.010

237. Kanda N, Tsuchida T, Tamaki K. Estrogen enhancement of antidouble-stranded DNA antibody and immunoglobulin G production in peripheral blood mononuclear cells from patients with systemic lupus erythematosus. Arthritis Rheum. (1999) 42:328-37. doi: 10.1002/15290131(199902)42:2<328::AID-ANR16>3.0.CO;2-\#

238. Steinberg AD, Melez KA, Raveche ES, Reeves JP, Boegel WA, Smathers $\mathrm{PA}$, et al. Approach to the study of the role of sex hormones in autoimmunity. Arthritis Rheum. (1979) 22:1170-6. doi: 10.1002/art.17802 21103

239. Bynoe MS, Grimaldi CM, Diamond B. Estrogen up-regulates Bcl-2 and blocks tolerance induction of naïve B cells. Proc Natl Acad Sci USA.(2000) 97:2703-8. doi: 10.1073/pnas.040577497

240. Mok CC, Lau CS, Ho CT, Lee KW, Mok MY, Wong RW. Safety of hormonal replacement therapy in postmenopausal patients with systemic lupus erythematosus. Scand J Rheumatol. (1998) 27:342-6. doi: 10.1080/03009749850154357

241. Mok CC, Lau CS, Wong RW. Use of exogenous estrogens in systemic lupus erythematosus. Semin Arthritis Rheum. (2001) 30:426-35. doi: 10.1053/sarh.2001.22498

242. Jungers P, Dougados M, Pelissier C, Kuttenn F, Tron F, Lesavre $\mathrm{P}$, et al. Influence of oral contraceptive therapy on the activity of systemic lupus erythematosus. Arthritis Rheum. (1982) 25:618-23. doi: 10.1002/art.1780250603

243. Lateef A, Petri M. Hormone replacement and contraceptive therapy in autoimmune diseases. J Autoimmun. (2012) 38:J1706. doi: 10.1016/j.jaut.2011.11.002

244. Polari L, Wiklund A, Sousa S, Kangas L, Linnanen T, Härkönen P, et al. SERMs promote anti-inflammatory signaling and phenotype of CD14+ cells. Inflammation. (2018) 41:1-15. doi: 10.1007/s10753-018-0763-1

245. Walker SE. Estrogen and autoimmune disease. Clin Rev Allergy Immunol. (2011) 40:60-5. doi: 10.1007/s12016-010-8199-X

246. Li R, Xu W, Chen Y, Qiu W, Shu Y, Wu A, et al. Raloxifene suppresses experimental autoimmune encephalomyelitis and NF- $\kappa$ Bdependent CCL20 expression in reactive astrocytes. PLoS ONE. (2014) 9:e94320. doi: 10.1371/journal.pone.0094320

247. Tomer Y. Mechanisms of autoimmune thyroid diseases: from genetics to epigenetics. Ann Rev Pathol. (2014) 9:14756. doi: 10.1146/annurev-pathol-012513-104713

248. Merrill SJ, Mu Y. Thyroid autoimmunity as a window to autoimmunity: an explanation for sex differences in the prevalence of thyroid autoimmunity. $J$ Theor Biol. (2015) 375:95-100. doi: 10.1016/j.jtbi.2014.12.015

249. Antonelli A, Ferrari SM, Corrado A, Di Domenicantonio A, Fallahi P. Autoimmune thyroid disorders. Autoimmun Rev. (2015) 14:17480. doi: 10.1016/j.autrev.2014.10.016

250. Brinton RD, Yao J, Yin F, Mack WJ, Cadenas E. Perimenopause as a neurological transition state. Nat Rev Endocrinol. (2015) 11:393. doi: $10.1038 /$ nrendo. 2015.82

251. Chitnis T. Role of puberty in multiple sclerosis risk and course. Clin Immunol. (2013) 149:192-200. doi: 10.1016/j.clim.2013.03.014

252. Matarese G, Di Giacomo A, Sanna V, Lord GM, Howard JK, Di Tuoro A, et al. Requirement for leptin in the induction and progression of autoimmune encephalomyelitis. J Immunol. (2001) 166:5909-16. doi: 10.4049/jimmunol.166.10.5909
253. Horlick MB, Rosenbaum M, Nicolson M, Levine LS, Fedun B, Wang $J$, et al. Effect of puberty on the relationship between circulating leptin and body composition. J Clin Endocrinol Metab. (2000) 85:250918. doi: 10.1210/jcem.85.7.6689

254. Matarese G, Sanna V, Di Giacomo A, Lord GM, Howard JK, Bloom SR, et al. Leptin potentiates experimental autoimmune encephalomyelitis in SJL female mice and confers susceptibility to males. Eur J Immunol. (2001) 31:1324-32. doi: 10.1002/1521-4141(200105)31:5<1324::AIDIMMU1324>3.0.CO;2-Y

255. Popławska-Kita A, Siewko K, Telejko B, Kosciuszko-Zdrodowska M, Hryniewicka J, Szelachowska M, et al. Body mass analysis in patients with Hashimoto thyroiditis. Prog Health Sci. (2014) 4:18-23.

256. Elenkova A, Atanasova I, Kirilov G, Natchev E, Ivanova R, Kovatcheva $\mathrm{R}$, et al. Autoimmune hypothyroidism is three times more frequent in female prolactinoma patients compared to healthy women: data from a cross-sectional case-control study. Endocrine. (2017) 57:48693. doi: 10.1007/s12020-017-1372-8

257. Wang X, Qiao Y, Yang L, Song S, Han Y, Tian Y, et al. Leptin levels in patients with systemic lupus erythematosus inversely correlate with regulatory $\mathrm{T}$ cell frequency. Lupus. (2017) 26:1401-6. doi: 10.1177/0961203317703497

258. Gaudreau MC, Johnson BM, Gudi R, Al-Gadban MM, Vasu C. Gender bias in lupus: does immune response initiated in the gut mucosa have a role? Clin Exp Immunol. (2015) 180:393-407. doi: 10.1111/cei.12587

259. Ravelli A, Martini A. Juvenile idiopathic arthritis. Lancet. (2007) 369:76778. doi: 10.1016/S0140-6736(07)60363-8

260. Ober C, Loisel DA, Gilad Y. Sex-specific genetic architecture of human disease. Nat Rev Genet. (2008) 9:911. doi: 10.1038/nrg2415

261. Katoh H, Zheng P, Liu Y. FOXP3: Genetic and epigenetic implications for autoimmunity. J Autoimmun. (2013) 41:72-8. doi: 10.1016/j.jaut.2012.12.004

262. Farh KKH, Marson A, Zhu J, Kleinewietfeld M, Housley WJ, Beik S, et al. Genetic and epigenetic fine mapping of causal autoimmune disease variants. Nature. (2014) 518:337. doi: 10.1038/nature13835

263. Ellis JA, Munro JE, Chavez RA, Gordon L, Joo JE, Akikusa JD, et al. Genomescale case-control analysis of CD4+ T-cell DNA methylation in juvenile idiopathic arthritis reveals potential targets involved in disease. Clin Epigenet. (2012) 4:20. doi: 10.1186/1868-7083-4-20

264. Ballestar E. Epigenetic alterations in autoimmune rheumatic diseases. Nat Rev Rheumatol. (2011) 7:263. doi: 10.1038/nrrheum.2011.16

265. Hewagama A, Richardson B. The genetics and epigenetics of autoimmune diseases. J Autoimmun. (2009) 33:3-11. doi: 10.1016/j.jaut.2009.03.007

266. Saito S, Nakashima A, Shima T. Ito $\mathrm{M}$, Th1/Th2/Th17 and regulatory T-cell paradigm in pregnancy. Am J Reprod Immunol. (2010) 63:60110. doi: 10.1111/j.1600-0897.2010.00852.x

267. Krishnan L, Guilbert LJ, Wegmann TG, Belosevic M, Mosmann TR. T helper 1 response against Leishmania major in pregnant C57BL/6 mice increases implantation failure and fetal resorptions. Correlation with increased IFNgamma and TNF and reduced IL-10 production by placental cells. $J$ Immunol. (1996) 156:653-62.

268. Al-Shammri S, Rawoot P, Azizieh F, AbuQoora A, Hanna M, Saminathan TR, et al. Th1/Th2 cytokine patterns and clinical profiles during and after pregnancy in women with multiple sclerosis. J Neurol Sci. (2004) 222:217. doi: 10.1016/j.jns.2004.03.027

269. Elenkov IJ, Wilder RL, Bakalov VK, Link AA, Dimitrov MA, Fisher S, et al. IL-12, TNF- $\alpha$, and hormonal changes during late pregnancy and early postpartum: implications for autoimmune disease activity during these times. J Clin Endocrinol Metab. (2001) 86:4933-8. doi: 10.1210/jcem.86.10.7905

270. Salem ML. Estrogen, a double-edged sword: modulation of TH1- and TH2-mediated inflammations by differential regulation of $\mathrm{TH} 1 / \mathrm{TH} 2$ cytokine production. Curr Drug Targets Inflamm Allergy. (2004) 3:97104. doi: 10.2174/1568010043483944

271. Stenager E, Stenager EN, Jensen K. Effect of pregnancy on the prognosis for multiple sclerosis. A 5-year follow up investigation. Acta Neurol Scand. (1994) 90:305-8. doi: 10.1111/j.1600-0404.1994.tb02728.x

272. D'Hooghe BM, Nagels G, Uitdehaag BM. Long-term effects of childbirth in MS. J Neurol Neurosurg Psychiatry. (2010) 81:38-41. doi: 10.1136/jnnp.2008.163816 
273. Pakpoor J, Disanto G, Lacey MV, Hellwig K, Giovannoni G, Ramagopalan SV. Breastfeeding and multiple sclerosis relapses: a meta-analysis. J Neurol. (2012) 259:2246-8. doi: 10.1007/s00415-012-6553-z

274. Shelly S, Boaz M, Orbach H. Prolactin and autoimmunity. Autoimmun Rev. (2012) 11:A465-70. doi: 10.1016/j.autrev.2011.11.009

275. Langer-Gould A, Gupta R, Huang S, Hagan A, Atkuri K, Leimpeter $\mathrm{AD}$, et al. Interferon- $\gamma$-producing $\mathrm{T}$ Cells, pregnancy, and postpartum relapses of multiple sclerosis. Arch Neurol. (2010) 67:51-7. doi: 10.1001/archneurol.2009.304

276. Wender-Ozegowska E, MichaŁOwska-Wender G, Zawiejska A, Pietryga M, Brazert J, Wender M. Concentration of chemokines in peripheral blood in first trimester of diabetic pregnancy. Acta Obstetr Gynecol Scand. (2008) 87:14-9. doi: 10.1080/00016340701698724

277. Sica A, Wang JM, Colotta F, Dejana E, Mantovani A, Oppenheim JJ, et al. Monocyte chemotactic and activating factor gene expression induced in endothelial cells by IL-1 and tumor necrosis factor. I Immunol. (1990) 144:3034-8.

278. Ramhorst RE, García VE, Corigliano A, Rabinovich GA, Fainboim L. Identification of RANTES as a novel immunomodulator of the maternal allogeneic response. Clin Immunol. (2004) 110:71-80. doi: 10.1016/j.clim.2003.09.011

279. Dragin N, Bismuth J, Cizeron-Clairac G, Biferi MG, Berthault C, Serraf A, et al. Estrogen-mediated downregulation of AIRE influences sexual dimorphism in autoimmune diseases. J Clin Invest. (2016) 126:152537. doi: $10.1172 /$ JCI81894

280. Bacon ER, Mishra A, Wang Y, Desai MK, Yin F, Brinton RZ. Neuroendocrine aging precedes perimenopause and is regulated by DNA methylation. Neurobiol Aging. (2019) 74:213-24. doi: 10.1016/j.neurobiolaging.2018.09.029

281. Çogulu Ö. Endocrine disrupters and epigenetics. J Clin Res Pediatr Endocrinol. (2015) 7(Suppl 2):77-92. Available online at: http://cms.galenos. com.tr/Uploads/Article_10664/26-27.pdf

282. Jasiulionis MG. Abnormal epigenetic regulation of immune system during aging. Front Immunol. (2018) 9:197. doi: 10.3389/fimmu.2018.00197

283. Grolleau-Julius A, Ray D, Yung RL. The role of epigenetics in aging and autoimmunity. Clin Rev Allergy Immunol. (2010) 39:42-50. doi: 10.1007/s12016-009-8169-3

284. Metter EJ, Pearson J, Tobin JD, Harman SM, Blackman MR. Longitudinal effects of aging on serum total and free testosterone levels in healthy men. $J$ Clin Endocrinol Metab. (2001) 86:724-31. doi: 10.1210/jcem.86.2.7219

285. Kular L, Castelo-Branco G, Jagodic M. Chapter 10 - Epigenetics and multiple sclerosis. In: Yasui DH, Peedicayil J, Grayson DR, editors. Neuropsychiatric Disorders and Epigenetics. Boston, MA: Academic Press (2017). p. 185-213.

286. Hedrich CM. Mechanistic aspects of epigenetic dysregulation in SLE. Clin Immunol. (2018) 196:3-11. doi: 10.1016/j.clim.2018.02.002

287. Scharer C, Blalock E, Barwick BG, Gandham B, Neary B, Sanz I, et al. Pathogenic epigenetic programming of expanded B cell subsets in systemic lupus erythematosus. J Immunol. (2017) 198:54.13. Available online at: http://www.jimmunol.org/content/198/1_Supplement/54.13.abstract

288. Klein K, Karouzakis E, Gay S. Rheumatoid arthritis and epigenetics. In: The Epigenetics of Autoimmunity. (2018). p. 149-66. doi: 10.1016/B978-0-12-809912-4.00007-6
289. Wang Z, Xie Z, Lu Q, Chang C, Zhou Z. Beyond genetics: what causes type 1 diabetes. Clin Rev Allergy Immunol. (2017) 52:27386. doi: 10.1007/s12016-016-8592-1

290. Chandra A, Ray A, Senapati S, Chatterjee R. Genetic and epigenetic basis of psoriasis pathogenesis. Mol Immunol. (2015) 64:313-23. doi: 10.1016/j.molimm.2014.12.014

291. Toro CA, Aylwin CF, Lomniczi A. Hypothalamic epigenetics driving female puberty. J Neuroendocrinol. (2018) 30:e12589. doi: 10.1111/jne. 12589

292. Thompson E, Nicodemus-Johnson J, Kim K, Gern JE, Jackson DJ, et al. C21 OMICS IN LUNG DISEASE: puberty-associated dna methylation changes in females are near estrogen responsive genes and implicated in immune processes. Am J Respir Crit Care Med. (2017) 195:A4970. Available online at: https://search.proquest.com/openview/ f9bcfca4997a9c079e97bc902233fa92/1?pq- origsite $=$ gscholar\&cbl $=40575$

293. Dang MN, Buzzetti R, Pozzilli P. Epigenetics in autoimmune diseases with focus on type 1 diabetes. Diabetes Metab Res Rev. (2013) 29:818. doi: 10.1002/dmrr.2375

294. Asadipour M, Hassan-Zadeh V, Aryaeian N, Shahram F, Mahmoudi M. Histone variants expression in peripheral blood mononuclear cells of patients with rheumatoid arthritis. Int J Rheuma Dis. (2018) 21:18317. doi: 10.1111/1756-185X.13126

295. Markle JG, Frank DN, Mortin-Toth S, Robertson CE, Feazel LM, Rolle-Kampczyk U, et al. Sex differences in the gut microbiome drive hormone-dependent regulation of autoimmunity. Science. (2013) 339:10848. doi: 10.1126/science. 1233521

296. Fairweather D, Frisancho-Kiss S, Rose NR. Sex differences in autoimmune disease from a pathological perspective. Am J Pathol. (2008) 173:6009. doi: 10.2353/ajpath.2008.071008

297. Lerner A, Jeremias P, Matthias T. The world incidence and prevalence of autoimmune diseases is increasing. Int J Celiac Dis. (2015) 3:1515. doi: 10.12691/ijcd-3-4-8

298. Lohi S, Mustalahti K, Kaukinen K, Laurila K, Collin P, Rissanen H, et al. Increasing prevalence of coeliac disease over time. Aliment Pharmacol Ther. (2007) 26:1217-25. doi: 10.1111/j.1365-2036.2007. 03502.x

299. A.A.Association RD. The Cost Burden of Autoimmune Disease: The Latest Front in the War on Healthcare Spending. Eastpointe, MI: American Autoimmune Related Diseases Association (2011).

300. NIH. NIH Categorical Spending. National Institutes of Health (2018). Available online at: https://report.nih.gov/categorical_spending.aspx

Conflict of Interest Statement: The authors declare that the research was conducted in the absence of any commercial or financial relationships that could be construed as a potential conflict of interest.

Copyright () 2019 Desai and Brinton. This is an open-access article distributed under the terms of the Creative Commons Attribution License (CC BY). The use, distribution or reproduction in other forums is permitted, provided the original author(s) and the copyright owner(s) are credited and that the original publication in this journal is cited, in accordance with accepted academic practice. No use, distribution or reproduction is permitted which does not comply with these terms. 